\title{
FEEDING ACTIVITY, RATE OF CONSUMPTION, DAILY RATION \\ AND PREY SELECTION OF MAJOR PREDATORS \\ IN JOHN DAY RESERVOIR, 1986
}

ANNUAL REPORT

BY

Thomas P. Poe, Douglas E. Palmer, Hal C. Hansel, Steven Vigg, Peter T. Lofy, Stephen D. Duke, Michael J. Parsley, Linda

A. Prendergast, Randy Burkhart, and Craig Burley

U.S. Fish and Wildlife Service

Seattle National Fishery Research Center

Willard Field Station

Star Route

Cook, Washington 98605

Funded by

U.S. Department of Energy

Bonneville Power Administration

Fred Holm, Project Manager

Contract DI-AI79-82BP34796 
ABSTRACT

\begin{abstract}
This report summarizes activities in 1986 to determine the significance of predation on juvenile salmonids in John Day Reservoir. To estimate consumption of juvenile salmonids we used the composition of the natural diet of predators collected in the field and in the laboratory determined rate of gastric evacuation by predators. Salmonids were the single most important food item (by weight) for northern squawish (Ptychocheilus oregonensis) at McNary tailrace during all sampling periods and at John Day forebay during July. Salmonids accounted for $23.7 \%$ of the diet of walleye (Stizostedion vitreum vitreum) in July 1986, which was higher than in previous years
\end{abstract} (although the sample size examined was low). Salmonids contributed little to smallmouth bass (Micropterus dolomieui) diet but comprised about 25\% of the diet of channel catfish (Ictalurus punctatus). Composition of prey taxa in beach seine catches in July 1986 was similar to previous years with chinook salmon (Oncorhynchus tschawytscha), largescale sucker (Catostomus macrocheilus), and sand roller (Percopsis transmontana) dominating the catch.

Daily salmonid consumption rate estimates per predator were relatively high for northern squawfish, moderate for walleye, and low for smallmouth bass. On an areal basis, salmonid consumption was highest at the McNary Dam tailrace restricted zone in contrast to the other predator species which exhibit negligible impact there. On a temporal basis the highest consumption rates occurred June thru late July, with a pronounced maximum for northern squawfish in July. The 
estimated for predators in John Day Reservoir are generally consistent with values documented in the literature for predacious fishes, i.e. 0.5 to $6.0 \%$ body weight per day. 
This study was funded by Bonneville Power Administration. We wish to thank Fred Holm and other Bonneville Power Administration personnel for their assistance. Mike Gray, Doug Engle, Mark Manion, Doug Warrick, Vern Stofleth, and other Oregon Department of Fish and Wildlife personnel are thanked for providing assistance in the field. Our sincere thanks go to Michele Dehart of the Fish Passage Center for arranging spill closures at McNary Dam.

Special thanks are extended to Sandy Bayman for typing the report and to Bill Nelson, Lance Beckman, Ray Beamsderfer, and Bruce Rieman for their critical reviews of the report. 
1. Percent occurrence and weight of food items in digestive tracts of northern squawish ranging in length from 103 to $539 \mathrm{~mm}(\mathrm{X}=395.6 \mathrm{~mm})$, collected from John day reservoir, April 14 to August 1, 1986. Sample size and number of empty digestive tracts were 626 and 165, respectively. . . . . .

2. Mean number (X \#) and percent weight ( $\%$ WT) of salmonid (SAL) and non-salmonid (NSAL) fishes in the diet of a subsample of northern squawfish by predator length, John Day Reservoir, 1986. Lengths are midpoints of $50-\mathrm{mm}$ intervals. $\mathrm{N}=$ number of digestive tracts analyzed; $\mathrm{E}=$ number of empty digestive tracts. . . . . . . . . . . . . . . . . . .

3. Percent occurrence, percent weight and mean number of food items in digestive tracts of large northern squawfish (250-549 mm FL) by station, from John Day Reservoir, June 30 to Aug 1, 1986. Sample sizes and number of empty digestive tracts are inparentheses. . . . . . . . . . . . . . . . . . . . .

4. Percent occurrence, weight and mean number of food items in digestive tracts of large northern squawfish (250-539 $\mathrm{mm} \mathrm{FL}$ ) by sample period from McNary tailrace Restricted Zone, John Day Reservoir, 1986. Sample sizes and number of empty digestive tracts are in parentheses. . . . . . . . . . . . . . . .

5. Percent occurrence and weight of food items in-stomachs of

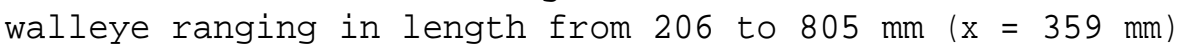
collected from John Day Reservoir, July 1986. Sample size and number of empty stomachs were 74 and 22, respectively. .

6. Percent occurrence, percent weight, and mean number of food items in stomachs of walleye by station from John Day Reservoir, during July, 1986. Sample size and number of empty stomachs are in parentheses. . . . . . . . . . . . . .

7. Percent occurrence and weight of food items in stomachs of smallmouth bass ranging in length from 82 to $452 \mathrm{~mm} \mathrm{FL}$ $(\mathrm{x}=219 \mathrm{~mm})$, collected from John Day Reservoir, July 1986. Sample size and number of empty stomachs were 955 and 109, respectively. . . . . . . . . . . . . . . . . . . . . . . 
List of Tables (cont).

$\underline{\text { Table }}$

$\underline{\text { Page }}$

8. Mean number $\mathrm{x} \#$ ) and percent weight (\%WT) of salmonid (SAL)

and non-salmonid (NSAL) fishes in the diet of smallmouth

bass by pedator length collected from John Day Reservoir,

July, 1986. Lengths are midpoints of $50 \mathrm{~mm}$ intervals.

$\mathrm{N}=$ number of digestive tracts analyzed; $\mathrm{E}=$ number of empty

digestive tracts. . . . . . . . . . . . . . . . . . .

9. Percent occurrence, percent weight, and mean number of food items in stomachs of smallmouth bass by station from John Day Reservoir, July 1986. Sample size and number of empty stomachs areinparentheses. . . . . . . . . . . . . . .

10. Total catch and catch per haul (in parentheses) of prey fish ( $\leq 250 \mathrm{~mm} \mathrm{FL}$ ) collected with a beach seine at all sampling locations in John Day Reservoir, July 1986. . . . . . . . .

11. Mean percent seine efficiency and 95\% confidence intervals (C.I.) for prey taxa captured over fine (sand) and coarse (sand-gravel-cobble) substrates in John Day Reservoir, 1985 and 1986. The results are back-transformed from normalized data. Where no significant difference (t-test, $\mathrm{P}<0.05$ ) exists between efficiency estimates for fine and coarse substrates, a weighted mean 을 efficiency was calculated. .

12. Daily consumption estimates of juvenile salmonids and total prey fish by northern squawfish $(n=3,099)$ in John Day Reservoir during 1983-1985; stratified by month for McNary tailrace restricted zone versus the remainder of the reseroivr. .. . . . . . . . . . . . . . . . .

13. Daily consumption estimates of juvenile salmonids (total prey fish in parentheses) by walleye in John Day Reservoir during 1983-1985; stratified by month. . . . . . . . . . . .

14. Daily consumption estimates of juvenile salmonid smolts and total preyfish by smallmouth bass $(\mathrm{n}=3,846)$ in John Day Reservoir during 1983-1985; stratified by month for McNary tailrace restricted zone versus the remainder of the reservoir. . . . . . . . . . . . . . . . . . 
INTRODUCTION

The Seattle National Fishery Research Center of the U.S. Fish and Wildlife Service (USFWS) is working in cooperation with the Oregon Department of Fish and Wildlife (ODFW) to determine the extent of predation on juvenile anadromous salmonids by northern squawfish (Ptychocheilus oregonensis), walleye (Stizostedion vitreum vitreum), smallmouth bass (Micropterus dolomieui), and channel catfish (Ictalurus punctatus) in John Day Reservoir. The three objectives which were identified in the original USFWS proposal and scheduled to be completed in 1988 are:

1) Determine the food habits, rate of consumption, daily ration, and feeding activity of major predators.

2) Determine the pattern of prey selection of major predators as a function of time and reservoir habitat.

3) Estimate the rate of gastric evacuation of major predators. Following consultation with personnel from ODFW and Bonneville Power Administration (BPA) additional objectives were added in 1984:

4) Determine the feasibility of regulating predation on juvenile salmonids.

5) Develop conceptual and predictive models of the predatorjuvenile salmonid relationship in John Day Reservoir.

This report includes progress in 1986 on activities by the USFWS to meet the first three objectives, and during the year the following sub-objectives were addressed: 
A. Complete the collection of field data to estimate consumption and describe food habits of northern squawfish, walleye, smallmouth bass, and channel catfish at all sampling locations during July.

B. Obtain detailed information to estimate consumption of juvenile salmonids by northern squawfish and channel catfish in the McNary tailrace restricted zone (RZ) from April-August.

C. Describe the composition, apparent abundance, and distribution of prey fishes in John Day Reservoir in July.

D. Estimate beach seine efficiency in collecting various prey species over different substrate types.

E. Estimate consumption of juvenile salmonids by northern squawfish and smallmouth bass, 1983-1985.

F. Obtain data to determine if fish health may influence prey selection of northern squawfish and channel catfish in the McNary tailrace RZ. 
METHODS

Food Habits

Techniques used to collect and process predatory fish and to analyze stomach contents were similar to those used previously (Gray et al. 1986). The 1986 sampling design, however, was modified in the following ways: (1) all predators were sampled for at least three 24 hr periods only during July at John Day forebay, Arlington, Irrigon, and McNary tailrace and (2) northern squawfish and channel catfish were collected with a boat electroshocker and bottom gill nets at the McNary tailrace RZ during eight 1 hr spill closures scheduled every other week from April 14 through August 7 (these samples were taken to gather additional data on predation in the RZ and to collect freshly ingested juvenile salmonids for histopathblogical examination).

The digestive tracts of northern squawfish collected from June 9 to August 1 were subsampled for processing and analysis in order to complete this report in a timely manner. Ten fish were randomly selected for processing from each station, sampling period, and 6 hr diel interval. When less than 10 fish were available all were analyzed.

Abundance and Distribution of Prey Fishes

Prey fishes (<250 mm) were collected during July using a $30.5 \mathrm{X}$ $2.4 \mathrm{~m}$ beach seine constructed of $6.4 \mathrm{~mm}$ knotless mesh nylon, with a $2.4 \mathrm{~m}$ bag. Main channel littoral habitats were sampled at McNary tailrace, Irrigon, Arlington, and John Day forebay. Backwater 
habitats were sampled at McNary tailrace (Plymouth slough) and Irrigon (Paterson slough). Each sampling station was seined twice during July; sampling and enumeration techniques followed Gray et al. (1985).

Peach Seine Efficiency

Seine efficiency estimates were completed during 1986 following the procedures outlined in 1985 (Palmer et al. 19861 with two exceptions: (1) we added an additional site near Rock Creek (river kilometer 366) and did not conduct experiments in the Paterson area, and (2) four to ten seine hauls were made to remove the majority of fish in the enclosure. Seine efficiency (SE) by species or genus was calculated by the equation:

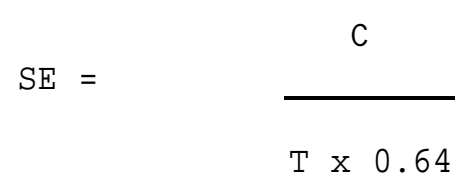

where (C) is the catch of a given species in the first haul; (T) is the total number of that species removed from the enclosure; and 0.64 is the ratio of the area covered by the seine on the first haul to the area enclosed by the block net. Data collected during 1986 were combined with the data collected during 1985. At least three estimates were required to obtain a mean efficiency. For statistical purposes, all estimates were normalized by an arcsine transformation. Since this transformation is poor at the extreme ends of the range (ie. 0.00 and 100 percent), 
the transformation was improved by replacing the proportion $0 /(\mathrm{T} \times 0.64)$ with $1 /[4(\mathrm{~T} \times 0.6411$ and $(\mathrm{T} \times 0.64) /(\mathrm{T} \times 0.64)$ with $1-1 /[4(\mathrm{~T} \times 0.6411$ prior to the transformation (Bartlett 1937). A paired t-test was employed to test the hypothesis that seine efficiency for a given species was equal ( $P>0.05$ ) over fine ( $<2 \mathrm{~mm}$ diameter) and coarse (2 - $250 \mathrm{~mm}$ diameter) substrates. If this hypothesis was not rejected at the stated level of significance, a weighted mean efficiency was calculated using the information from both substrates (Zar 1984).

Consumption Estimates

Techniques used for estimating daily consumption rates of juvenile salmonids by predators in John Day Reservoir were described in Palmer et al. (1986). The following is a more detailed description of the programs and stratification design used to make these estimates, including several modifications of the 1985 techniques.

Algorithms used in the data conversion programs to estimate digestion time for each prey fish item are derived from evacuation rate regression equations solved for time (Appendix Table 1). Northern squawfish and smallmouth bass regression equations were developed by Jean Beyer (1986) and equations for walleye by Wahl and Nielson (1985) and from Swenson (1972). The walleye evacuation rate regressions were determined separately for three prey size strata. Only one regression equation (prey sizes combined) was determined for northern squawfish and smallmouth bass; therefore, it was necessary to adjust the 
calculation of digestion time of individual prey fish by the ratio of individual prey weight to total stomach content weight.

Since Swenson's technique requires stratification of the die1 consumption calculation by prey size groups in order to accommodate calculation of potential predators, 11 arbitrary prey weight classes (10 $\mathrm{g}$ increments) were incorporated into northern squawfish and smallmouth bass programs. Ihe walleye calculation was stratified by the three weight classes pre-determined by the design of the evacuation rate experiments.

The total mass of food in a predator's stomach is an important determinant for digestion rate. Thus meal size is an important variable for predicting digestion time of a given prey fish. Meal size can be expressed simply as stomach content weight $(g)$ or as a ratio of stomach content weight to predator weight (mg/g). The latter expression standardizes the variable across predator sizes and eliminates the need for predator weight to be explicitly incorportated into the evacuation regression. A statistical disadvantage of using both meal size and individual prey weight as predictors, however, is that individual prey weight is a (varying) component of stomach content weight. As a result there is a lack of statistical independence among predictors.

Meal size was calculated separately for each prey fish in the stomach using the equation:

$$
\text { MSIZE }=\text { NONFISH }+ \text { ORIGWT }(1)+\operatorname{DIGWGT}(I) \text { * }
$$

where NONFISA is the digested weight of all nonfish food items; where 
ORIGWT(1) is the original weight of the given (i th) fish item; and DIGWGT(I)* is the digested weight of other prey fish, if that item was within $20 \%$ of the percent digestion and $10 \%$ original weight of the (i th) prey fish in question. Walleye meal sizes are expressed in terms of $\mathrm{mg} / \mathrm{g}$ in accordance with the equation of Wahl and Nielson (1985); northern squawfish and smallmouth bass meal sizes are calculated in terms of weight $(\mathrm{g})$ to be consistent with the evacuation regressions for those species.

Time for 90\% digestion of each prey size group [DTIMESO(K) I is required for the calculation of potential predators. The evacuation rate equations are modified to perform this calculation; species-specific algorithms are presented in Appendix Table 2. A meal size term is prerequisite for the calculation of $90 \%$ digestion time; mean meal size was empirically determined by prey size group, for the specific data set to be analyzed (Appendix Table 3). Percent digestion is set to 0.9 (smallmouth bass and walleye), or total grams evacuated is set to 0.9 times the mean meal size of each prey fish size group (northern squawfish).

Consumption estimates of juvenile salmonids and total prey fish by fish predators in John Day Reservoir were calculated for walleye, northern squawfish, and smallmouth bass for 1983-1985, and the data were analyzed by individual year as well as for the pooled three-year sample. The tabulations were stratified by calendar month (April-August) and by two reservoir areas-- McNary Dam tailrace restricted zone (RZ) and the remainder of the John Day Reservoir (except for walleye). Walleye data were pooled over the entire reservoir because of the small sample size. 
Histopathology of Juvenile Salmonids

\begin{abstract}
Juvenile salmonids for use in histopathological studies were collected from the Columbia River below McNary Dam and from stomachs of northern squawfish and channel catfish collected in the McNary tailrace RZ. Techniques used to preserve and process tissues, including the eye, brain, digestive tract, kidney, liver, spleen, heart, skin, muscle, gill, and pseudobranch were similar to those used previously (Palmer et al. 1986).
\end{abstract}

RESULTS

Food Habits of Northern Squawfish

In 1986, 1,856 northern squawfish were collected for food habits analysis. The digestive tracts of a subsample of 626 northern squawfish ranging from 103 to $539 \mathrm{~mm}$ in fork length (FL) were analyzed and 165 (26\%) of those were empty (the other 1,230 digestive tracts are still being analyzed). The percent occurrence and weight of food items in digestive tracts of northern squawish followed similar trends noted in previous years with amphipods, crayfish, mayflies, and salmonids the most frequently ingested items respectively, with salmonids dominating the diet by weight (Table 1). The percent weight and mean number of salmonid and non-salmonid fish in the diet generally increased with predator length (Table 2). The smallest northern squawfish to consume a fish was $247 \mathrm{~mm} \mathrm{FL}$, and the smallest to ingest a salmonid was $285 \mathrm{~mm}$ FL. 
Table 1. Percent occurrence and weight of food items in digestive tracts of northern squawfish ranging in length from 103 to $539 \mathrm{~mm}$ (X=395.6 mm), collected from John Day Reservoir, April 14 to August 1, 1986. Sample size and number of empty digestive tracts were 626 and 165, respectively.

\begin{tabular}{|c|c|c|}
\hline Food Item & $\begin{array}{c}\text { Percent } \\
\text { Occurrence }\end{array}$ & $\begin{array}{l}\text { Percent } \\
\text { Weight }\end{array}$ \\
\hline MOLLUSCA & 0.7 & to. 1 \\
\hline Pelecypoda & - & \\
\hline Corbicula manilensis & 0.6 & $<0.1$ \\
\hline Gastropoda & 0.1 & $<0.1$ \\
\hline CRUSTACEA & 31.9 & 11.6 \\
\hline Amphipoda & 20.4 & 2.2 \\
\hline Anisogammarus spp. & 1.5 & $<0.1$ \\
\hline De $\overline{\text { Corophium spp. }}$ & 19.9 & 2.2 \\
\hline Pacifastacus leniusculus & 13.0 & 7.2 \\
\hline Isopoda & 0.3 & $<0.1$ \\
\hline INSECTA & 33.2 & 3.7 \\
\hline Ephemeroptera & 21.7 & 1.2 \\
\hline Odonata & 0.1 & $<0.1$ \\
\hline Orthoptera & 1.5 & 0.6 \\
\hline Hemiptera & 1.1 & $<0.1$ \\
\hline Coleoptera & 3.3 & $<0.1$ \\
\hline Trichoptera & 0.3 & $<0.1$ \\
\hline Lepidoptera & 1.5 & 0.7 \\
\hline Diptera & 6.2 & $<0.1$ \\
\hline Homoptera & 0.4 & $<0.1$ \\
\hline Hymenoptera & 3.0 & 0.1 \\
\hline Unidentified Insecta & 7.3 & 0.8 \\
\hline \multicolumn{3}{|l|}{ AGNATHA } \\
\hline Petromyzontidae & 0.4 & 0.2 \\
\hline OSTEICHTHYES & 37.8 & 85.5 \\
\hline Salmonidae & 28.5 & 66.9 \\
\hline Oncorhynchus tshawytscha & 21.8 & 48.5 \\
\hline Salmo gairdneri & 3.0 & 13.4 \\
\hline Unidentified Salmonidae & 3.6 & 5.0 \\
\hline Cyprinidae & 0.7 & 1.3 \\
\hline Acrocheilus alutaceus & 0.3 & 0.5 \\
\hline $\begin{array}{l}\text { Mylocheilus caurinus } \\
\end{array}$ & 0.1 & 0.8 \\
\hline Cyprinus carpio & 0.1 & to. 1 \\
\hline \multicolumn{3}{|l|}{ Catostomidae } \\
\hline Catostomus spp. & 0.9 & 1.8 \\
\hline
\end{tabular}


Table 1 (cont).

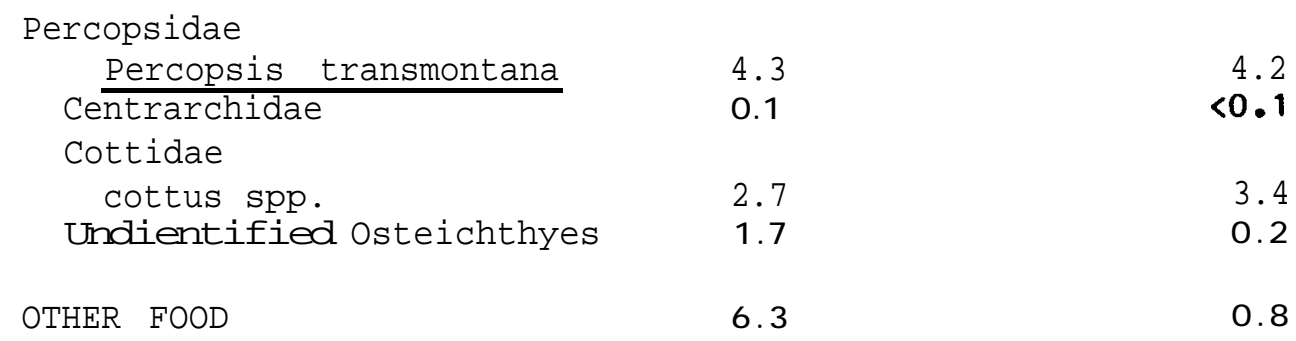


Table 2. Mean number $(x \#)$ and percent weight $\left(\frac{\circ}{6} \mathrm{WT}\right)$ of salmonid (SAL) and non-salmonid (NSAL) fishes in the diet of a subsample of northern squawfish by predator length, John Day Reservoir, 1986. Lengths are midpoints of SO-mm intervals. $\mathrm{N}=$ number of digestive tracts analyzed; $\quad E=$ number of empty digestive tracts.

\begin{tabular}{lrrrrrr}
\hline FORK & & & $\begin{array}{c}\overline{\mathbf{x}} \# \\
\text { SAL }\end{array}$ & $\begin{array}{l}\text { X\# } \\
\text { NSAL }\end{array}$ & $\begin{array}{r}\% \text { WT } \\
\text { SAL }\end{array}$ & $\begin{array}{r}\% \text { WT } \\
\text { NSAL }\end{array}$ \\
\hline & & & & & & \\
125 & 2 & 1 & 0.0 & 0.0 & 0.0 & 0.0 \\
175 & 2 & 1 & 0.0 & 0.0 & 0.0 & 0.0 \\
225 & 14 & 3 & 0.0 & 0.1 & 0.0 & 3.3 \\
275 & 50 & 12 & 0.1 & $<0.1$ & 41.1 & 11.1 \\
325 & 62 & 13 & 0.1 & 0.1 & 31.4 & 10.6 \\
375 & 123 & 32 & 0.3 & 0.1 & 56.3 & 8.4 \\
425 & 233 & 70 & 0.6 & 0.1 & 79.1 & 9.4 \\
475 & 127 & 31 & 0.8 & 0.1 & 82.1 & 12.8 \\
525 & 8 & 2 & 1.5 & 0.2 & 79.9 & 19.7 \\
& & & & & & \\
\hline
\end{tabular}


Fish and crustaceans contributed the most weight to the diet of large northern squawfish (250 - $550 \mathrm{~mm}$ FL) at McNary (McN), Irrigon (IRR) and Arlington (ARL) during July (Table 3). Insects, primarily Lepidoptera, contributed about the same percent weight (44.9\%) as fish for northern squawfish captured at John Day forebay (JDF). At stations immediately above and below dams, fish (primarily salmonids) contributed much more weight to the diet (MCN 96.3\%; JDF 42.5\%) than did crustaceans (MCN 2.4\%; JDF 11.0\%). In contrast, fish contributed a smaller percentage of weight to the total diet at the mid-reservoir (IRR $40.0 \%$; ARL $27.7 \%$ ), only a small portion of which were salmonids (IRR $0.00 \% ;$ ARL $6.12 \%$ ). At these latter stations, crustaceans made up the largest percentage of weight to the total diet (IRR 43.5\%; ARL $61.2 \%)$.

The mean number of fish eaten by large northern squawfish during July varied only slightly between stations, with the exception of MCNary (MCN 1.2; IRR 0.2; ARL 0.1; JDF 0.2). The mean number of salmonids eaten followed a similar trend as all fish in general (McN 1.0; IRR 0.0; ARL 0.0; JDF 0.1).

The contribution of fish to the diet of large northern squawish captured at McNary tailrace RZ from April 14 to August 1 ranged from 84.9\% by weight in June to $96.3 \%$ during July (Table 4). Salmonids contributed the majority of the total fish weight, ranging from $73.0 \%$ in June to $89.4 \%$ in May; crustaceans contributed a much smaller percentage, ranging from $2.4 \%$ in July to $6.6 \%$ in April. The mean number of fish in the diet increased from 0.6 in April to 1.2 during 
Table 3. Percent occurrence, percent weight and mean number of food items in digestive tracts of large northern squawfish (250-549 mm FL) by station, from John Day Reservoir, June 30 to Aug 1, 1986. Sample sizes and number of empty digestive tracts are in parentheses.

\begin{tabular}{|c|c|c|c|c|}
\hline Station & Food Item & $\begin{array}{c}\text { Percent } \\
\text { Occurrence }\end{array}$ & $\begin{array}{r}\text { Percent } \\
\text { Weight }\end{array}$ & $\begin{array}{l}\text { Mean } \\
\text { Number }\end{array}$ \\
\hline \multirow{7}{*}{$\begin{array}{l}\text { McNary tailrace } \\
(\mathbf{7 7}, \mathbf{2 2})\end{array}$} & Mollusca & 0.0 & 0.0 & 0.0 \\
\hline & Crustacea & 22.0 & 2.4 & 14.9 \\
\hline & Insecta & 16.8 & 0.8 & 0.4 \\
\hline & Osteicthyes & 49.3 & .96 .3 & 1.2 \\
\hline & Salmonids & 42.8 & 86.1 & 1.0 \\
\hline & Non-Salmonids & 6.5 & 10.2 & 0.2 \\
\hline & Other Food & 2.5 & 0.3 & to. 1 \\
\hline \multirow{7}{*}{$\begin{array}{l}\text { Irrigon } \\
(\mathbf{3 7 , 1 1 )}\end{array}$} & Molusca & 5.4 & 0.1 & 0.1 \\
\hline & Crustacea & 29.7 & 43.5 & 0.5 \\
\hline & Insecta & 35.1 & 7.4 & 0.6 \\
\hline & Osteicthyes & 21.6 & 40.0 & 0.2 \\
\hline & Salmonids & 0.0 & 0.0 & 0.0 \\
\hline & Non-Salmonids & 21.6 & 40.0 & 0.2 \\
\hline & Other Food & 8.1 & 8.6 & 0.1 \\
\hline \multirow{7}{*}{$\begin{array}{c}\text { Arlington } \\
(65,19)\end{array}$} & Mollusca & 0.0 & 0.0 & 0.0 \\
\hline & Crustacea & 56.9 & 61.2 & 0.9 \\
\hline & Insecta & 38.4 & 7.9 & 2.2 \\
\hline & Osteicthyes & 12.3 & 27.7 & 0.1 \\
\hline & Salmonids & 3.0 & 1.7 & to. 1 \\
\hline & Non-Salmonids & 9.3 & 26.0 & 0.1 \\
\hline & Other Food & 7.7 & 3.0 & 0.1 \\
\hline \multirow{7}{*}{$\begin{array}{l}\text { John Day forebay } \\
(\mathbf{7 7}, \mathbf{2 5 )}\end{array}$} & Mollusca & 0.0 & 0.0 & 0.0 \\
\hline & Crustacea & 14.2 & 11.0 & 11.5 \\
\hline & Insecta & 46.7 & 44.9 & 8.6 \\
\hline & Osteicthyes & 14.2 & 42.5 & 0.2 \\
\hline & Salmonids & 7.7 & 30.4 & 0.1 \\
\hline & Non-salmonids & 6.5 & 12.1 & 0.1 \\
\hline & Other Food & 11.6 & 1.3 & 0.2 \\
\hline
\end{tabular}


Table 4. Percent occurrence, weight and mean number of food items in digestive tracts of large northern squawfish $(250-539 \mathrm{~mm} \mathrm{FL})$ by sample period from McNary tailrace Restricted Zone, John Day Reservoir, 1986. Sample sizes and number of empty digestive tracts are in parentheses.

\begin{tabular}{|c|c|c|c|c|}
\hline Date & Food Item & $\begin{array}{c}\text { Percent } \\
\text { Occurrence }\end{array}$ & $\begin{array}{l}\text { Percent } \\
\text { Weight }\end{array}$ & $\begin{array}{l}\text { Mean } \\
\text { Number }\end{array}$ \\
\hline \multirow{7}{*}{$\begin{array}{l}\text { Apr } 14-\text { May } 1 \\
\quad(119,251\end{array}$} & Mollusca & 0.0 & 0.0 & 0.0 \\
\hline & Crustacea & 41.1 & 6.6 & 26.9 \\
\hline & Insecta & 37.8 & 0.7 & 0.8 \\
\hline & Osteicthyes & 41.1 & 91.3 & 0.6 \\
\hline & Salmonidae & 27.7 & 78.1 & 0.4 \\
\hline & Non-Salmonids & 13.4 & 13.2 & 0.2 \\
\hline & Other Food & 7.5 & 0.2 & $<0.1$ \\
\hline \multirow{7}{*}{$\begin{array}{l}\text { May } 2 \text { - May } 31 \\
\quad(197,491\end{array}$} & Mollusca & 0.0 & 0.0 & 0.0 \\
\hline & Crus tacea & 30.4 & 2.8 & 15.2 \\
\hline & Insecta & 28.4 & 0.8 & 0.8 \\
\hline & Osteicthyes & 54.8 & 96.2 & 1.0 \\
\hline & Salmonidae & 47.7 & 89.4 & 0.9 \\
\hline & Non-Salmonids & 7.1 & 6.8 & 0.1 \\
\hline & Other Food & 2.5 & $<0.1$ & $<0.1$ \\
\hline \multirow{7}{*}{$\begin{array}{l}\text { Jun } 1-\text { Jun } 29 \\
(30,9)\end{array}$} & Mollusca & 6.6 & 1.8 & 0.1 \\
\hline & Crustacea & 16.6 & 6.1 & 2.6 \\
\hline & Insecta & 20.0 & 1.0 & 0.6 \\
\hline & Osteicthyes & 46.6 & 84.9 & 0.8 \\
\hline & Salmonidae & 36.6 & 73.0 & 0.7 \\
\hline & Non-Salmonids & 10.0 & 11.9 & 0.1 \\
\hline & Other Food & 16.6 & 6.0 & 0.2 \\
\hline \multirow{7}{*}{$\begin{array}{l}\operatorname{Jun} 30-\text { Aug } 1 \\
(\mathbf{7 7}, 22)\end{array}$} & Mollusca & 0.0 & 0.0 & 0.0 \\
\hline & Crus tacea & 22.0 & 2.4 & 14.9 \\
\hline & Insecta & 16.8 & 0.8 & 0.4 \\
\hline & Osteicthyes & 49.3 & 96.3 & 1.2 \\
\hline & Salmonidae & 42.8 & 86.1 & 1.0 \\
\hline & Non-Salmonids & 6.5 & 10.2 & 0.2 \\
\hline & Other Food & 2.5 & 0.3 & to. 1 \\
\hline
\end{tabular}


July; mean number of salmonids ingested increased from 0.4 in April to 1.0 in July (Table 4).

Fish were an insignificant component of the diet for northern squawfish 100 to $249 \mathrm{~mm} \mathrm{FL}$ (Appendix Tables 4 and 5). As in previous years, crustaceans and insects were the dominant food items of this size group at all sample stations for all sample periods.

Food Habits of Walleye

Stomach contents of 74 walleye (collected in July) ranging from

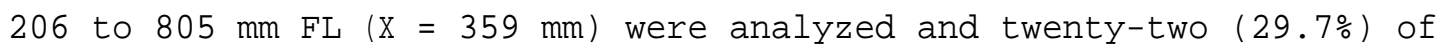
the walleye collected had empty stomachs. The diet of walleye was composed primarily of fish, accounting for over 99\% of the total weight of food consumed during July (Table 5). Percposids accounted for the highest percent by weight (45.8\%) among five families of fish identified in the diet. Salmonids were the second highest percent by weight at $23.7 \%$, with cyprinids contributing $20.6 \%$, cottids $7.3 \%$, and catostomids $0.5 \%$

Fish comprised over 99\% of the diet by weight during July at all areas (Table 6). Percopsids (35.2\%) and cyprinids (31.4\%) were most important to the diet of walleye, however, salmonids did account for $20.7 \%$ by weight. Nine walleye at Irrigon and seven walleye at Arlington were captured during July with food in their stomachs. Fish accounted for more than 99\% of the diet by weight at both stations (Table 6). Salmonids were less important in the diet at Irrigon (8.0\%) than at Arlington (84.1\%); no walleye were captured at John Day forebay. 


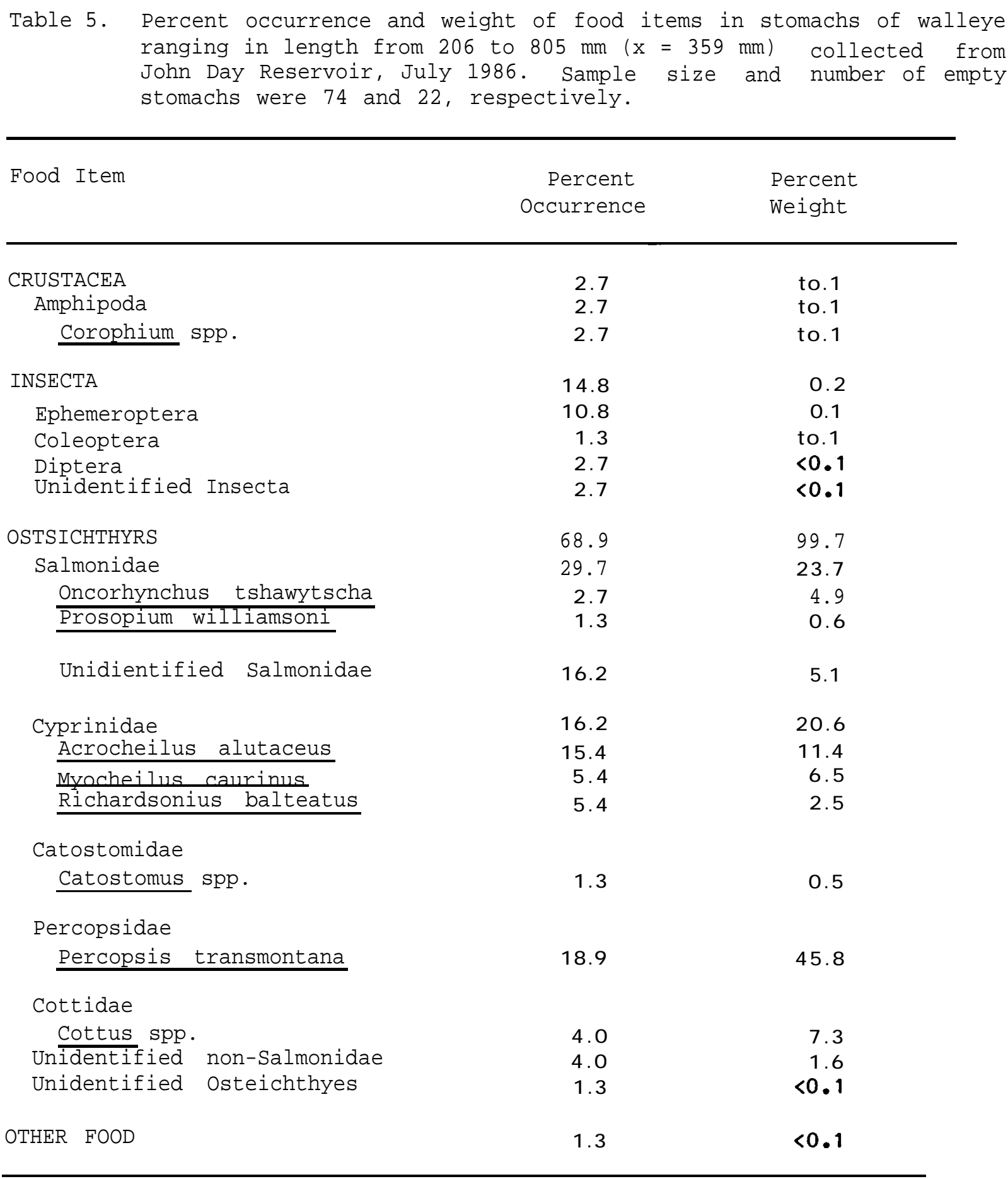


Table 6. Percent occurrence, percent weight, and mean number of food items in stomachs of walleye by station from John Day Reservoir, July, 1986. Sample size and number of empty stomachs are in parentheses.

\begin{tabular}{|c|c|c|c|c|}
\hline Date & Food Item & $\begin{array}{c}\text { Percent } \\
\text { Occurrence }\end{array}$ & $\begin{array}{l}\text { Percent } \\
\text { Weight }\end{array}$ & $\begin{array}{l}\text { Mean } \\
\text { Number }\end{array}$ \\
\hline \multirow{7}{*}{$\begin{array}{l}\text { McNary tailrace } \\
\quad(55,191\end{array}$} & Mollusca & 0.0 & 0.0 & 0.0 \\
\hline & Crustacea & 3.6 & to. 1 & 0.1 \\
\hline & Insecta & 10.9 & 0.2 & 0.7 \\
\hline & Osteicthyes & 63.6 & 99.7 & 1.0 \\
\hline & Salmonids & 27.2 & 20.7 & 0.3 \\
\hline & Non-Salmonids & 36.4 & 79.0 & 0.7 \\
\hline & Other Food & 0.0 & 0.0 & 0.0 \\
\hline \multirow{7}{*}{$\begin{array}{r}\text { Irrigon } \\
(\mathbf{1 0}, \mathbf{1})\end{array}$} & Mollusca & 0.0 & 0.0 & 0.0 \\
\hline & Crustacea & 0.0 & 0.0 & 0.0 \\
\hline & Insecta & 20.0 & 0.1 & 0.2 \\
\hline & Osteicthyes & 90.0 & 99.8 & 2.7 \\
\hline & Salmonids & 20.0 & 8.0 & 0.4 \\
\hline & Non-Salmonids & 70.0 & 91.8 & 2.3 \\
\hline & Other Food & 0.0 & 0.0 & 0.0 \\
\hline \multirow{7}{*}{$\begin{array}{l}\text { Arlington } \\
(9,2)\end{array}$} & Mollusca & 0.0 & 0.0 & 0.0 \\
\hline & Crustacea & 0.0 & 0.0 & 0.0 \\
\hline & Insecta & 33.3 & 0.1 & 0.3 \\
\hline & Osteicthyes & 77.7 & 99.8 & 1.0 \\
\hline & Salmonids & 55.5 & 84.1 & 0.6 \\
\hline & Non-Salmonids & 22.2 & 15.7 & 0.4 \\
\hline & Other Food & 0.0 & 0.0 & 0.0 \\
\hline
\end{tabular}


Food Habits of Smallmouth Sass

Stomach contents of 955 smallmouth bass ranging from 82 to $452 \mathrm{~mm}$ FL $(x=219 \mathrm{~mm})$, were examined; stomachs of 109 fish were empty. Fish and crustaceans were the major food items by weight in the diet of smallmouth bass during July, contributing $76 \%$ and $22 \%$ by weight to the diet (Table 7). The primary fish taxa consumed by weight were cottids (23.4\%), catostomids (22.3\%), and cyprinids (12.3\%). Salmonids accounted for $6.7 \%$ by weight of the smallmouth bass diet. Crayfish comprised over 99\% of the crustaceans consumed.

The mean number of fish ingested was generally greater for larger smallmouth bass (Table 8). The percent weight of salmonids in the diet was highest in smallmouth bass ranging from 150 to $299 \mathrm{~mm} \mathrm{FL}$. However, the mean number of salmonids consumed per smallmouth bass was 0.1 or less for all length groups; the smallest bass to ingest a salmonid was $140 \mathrm{~mm} \mathrm{FL.}$

The percent weight of fish in the diet of smallmouth bass decreased as the percent weight of crustaceans increased (Table 9). At McNary tailrace and Irrigon, the percent of fish consumed was $97.3 \%$ and 94.7\%, while the percent weight of crustaceans was $1.0 \%$ and $2.7 \%$, respectively. At Arlington and John Day forebay, the percent weight of fish decreased to $58.1 \%$ and $61.5 \%$, and the percent weight of crustaceans increased to $40.8 \%$ and $37.2 \%$, respectively. The mean number of fish consumed per smallmouth bass was correspondingly higher at McNary tailrace (1.1) and Irrigon (1.2) than at Arlington (0.7) and John Day forebay (0.4). 
Table 7. Percent occurrence and weight of food items in stomachs of smallmouth bass ranging in length from 82 to $452 \mathrm{~mm} \mathrm{FL}$ $(x=219 \mathrm{~mm})$, collected from John Day Reservoir, July 1986. Sample size and number of empty stomachs were 955 and 109, respectively.

\begin{tabular}{|c|c|c|}
\hline Food Item & $\begin{array}{c}\text { Percent } \\
\text { Occurrence }\end{array}$ & $\begin{array}{l}\text { Percent } \\
\text { Weight }\end{array}$ \\
\hline MOLLUSCA & 0.6 & to. 0.1 \\
\hline Pelecypoda & 0.6 & $<0.1$ \\
\hline Corbicula manilensis & 0.1 & $<0.1$ \\
\hline Gastropoda & 0.5 & $<0.1$ \\
\hline CRUSTACEA & 50.2 & 22.4 \\
\hline Cladocera & 6.5 & $<0.1$ \\
\hline Amphipoda & 19.0 & 0.1 \\
\hline Anisogammarus SPP. & 8.6 & $<0.1$ \\
\hline Corophium spp. & 14.8 & $<0.1$ \\
\hline Unidentified Amphipoda & 0.1 & to. 1 \\
\hline Decapoda & 39.0 & 22.2 \\
\hline Pacifastacus leniusculus & 37.1 & 22.2 \\
\hline$\overline{\text { Copepoda }}$ & 1.7 & to. 1 \\
\hline Isopoda & 0.2 & $<0.1$ \\
\hline INSECTA & 32.9 & 0.7 \\
\hline Ephemeroptera & 9.8 & 0.2 \\
\hline $\begin{array}{l}\text { Odonata } \\
\text { Orthoptera }\end{array}$ & $\begin{array}{l}1.5 \\
0.6\end{array}$ & $\begin{array}{r}0.1 \\
<0.1\end{array}$ \\
\hline Thysanoptera & 0.2 & $<0.1$ \\
\hline Hemiptera & 0.2 & $<0.1$ \\
\hline Coleoptera & 1.4 & $<0.1$ \\
\hline Trichoptera & 1.6 & $<0.1$ \\
\hline Lepidoptera & 0.2 & $<0.1$ \\
\hline Diptera & 17.3 & $<0.1$ \\
\hline Homoptera & 0.6 & $<0.1$ \\
\hline Hymenoptera & 3.0 & 0.1 \\
\hline Unidentified Insecta & 6.5 & $<0.1$ \\
\hline OSTEICHTHYES & 52.1 & 76.0 \\
\hline Alosa sapidissima & 0.1 & to.1 \\
\hline Salmonidae & 6.3 & 6.7 \\
\hline Oncorhynchus tshawytscha & 3.0 & 5.1 \\
\hline Prosopium williamsoni & 0.3 & 0.4 \\
\hline Salmonid (Non-whitefish) & 1.1 & 0.8 \\
\hline Unidentified Salmonidae & 2.1 & 0.4 \\
\hline Cyprinidae & 3.5 & 12.5 \\
\hline
\end{tabular}


Table 7 (cont).

Richardsonius balteatus $\quad 0.1$

Myocheilus caurinus $\quad 2.5$

$<0.1$

$<0.1$

Acrocheilus alutaceus $\quad 0.5$

11.4

Ptychocheilus oregonensis $\quad 0.5$

0.9

Catostomidae

7.3

22.3

Catostomus spp.

7.3

22.3

Percopsidae

11.6

9.8

Percopsis transmontana

Centrarchidae

11.6

9.8

Cottidae

0.9

0.2

Cottus spp.

21.4

23.4

21.4

23.4

Unidentified non-Salmonidae

7.4

5.2

10.7

0.5

$<0.1$

Larval Fish

12.0

0.1 
Table 8. Mean number $(\overline{\mathbf{x}} \#)$ and percent weight $\left(\frac{\circ}{6}\right.$ WT) of salmonid (SAL) and non-salmonid (NSAL) fishes in the diet of smallmouth bass by predator length collected from John Day Reservoir, July, 1986. Lengths are midpoints of $50 \mathrm{~mm}$ intervals. $\mathrm{N}=$ number of digestive tracts analyzed; $E$ = number of empty digestive tracts.

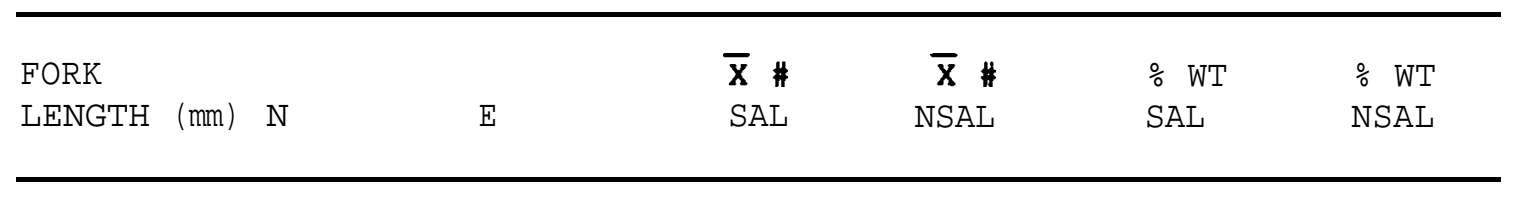

\begin{tabular}{rrrrrrr}
75 & 10 & 1 & 0.0 & 0.8 & 0.0 & 84.6 \\
125 & 103 & 7 & $<0.1$ & 0.6 & 0.8 & 45.5 \\
175 & 289 & 19 & $<0.1$ & 0.6 & 5.1 & 41.8 \\
225 & 309 & 42 & 0.1 & 0.5 & 15.2 & 51.6 \\
275 & 127 & 17 & $<0.1$ & 0.8 & 6.9 & 77.3 \\
325 & 65 & 10 & $t 0.1$ & 1.0 & 2.0 & 88.7 \\
375 & 36 & 7 & 0.0 & 1.0 & 0.0 & 97.8 \\
425 & 15 & 5 & 0.0 & 1.0 & 0.0 & 98.9 \\
475 & 1 & 1 & 0.0 & 0.0 & 0.0 & 0.0 \\
\hline
\end{tabular}


Table 9. Percent occurrence, percent weight, and mean number of food items in stomachs of smallmouth bass by station from John Day Reservoir, July 1986. Sample size and number of empty stomachs are in parentheses.

\begin{tabular}{|c|c|c|c|c|}
\hline Date & Food Item & $\begin{array}{c}\text { Percent } \\
\text { Occurrence }\end{array}$ & $\begin{array}{l}\text { Percent } \\
\text { Weight }\end{array}$ & $\begin{array}{l}\text { Mean } \\
\text { Number }\end{array}$ \\
\hline \multirow{7}{*}{$\begin{array}{l}\text { McNary tailrace } \\
\quad(124,161\end{array}$} & Mollusca & 0.8 & to. 1 & $<0.1$ \\
\hline & Crustacea & 25.0 & 1.0 & 0.4 \\
\hline & Insecta & 34.6 & 0.8 & 0.8 \\
\hline & Osteicthyes & 68.5 & 97.0 & 1.1 \\
\hline & Salmonidae & 10.4 & 3.3 & 0.1 \\
\hline & Non-Salmonids & 58.1 & 93.7 & 1.0 \\
\hline & Other Food & 17.7 & 0.1 & 0.1 \\
\hline \multirow{6}{*}{$\begin{array}{l}\text { Irrigon } \\
\quad(320,381\end{array}$} & Mollusca & 1.2 & $<0.1$ & to. 1 \\
\hline & $\begin{array}{l}\text { Crustacea } \\
\text { Insecta }\end{array}$ & $\begin{array}{l}20.0 \\
32.8\end{array}$ & $\begin{array}{l}2.7 \\
0.4\end{array}$ & $\begin{array}{l}4.0 \\
1.1\end{array}$ \\
\hline & Osteicthyes & 68.7 & 94.7 & 1.2 \\
\hline & Salmonidae & 10.3 & 8.2 & 0.1 \\
\hline & Non-Salmonids & 58.4 & 86.5 & 1.1 \\
\hline & Other Food & 17.8 & 0.1 & 0.1 \\
\hline \multirow{7}{*}{$\begin{array}{c}\text { Arlington } \\
(242,251\end{array}$} & Mollusca & 0.0 & 0.0 & 0.0 \\
\hline & Crustacea & 71.0 & 40.8 & 4.4 \\
\hline & Insecta & 34.2 & 0.91 & 1.0 \\
\hline & Osteicthyes & 41.7 & 58.1 & 0.7 \\
\hline & Salmonidae & 1.6 & 1.4 & to. 1 \\
\hline & Non-Salmonids & 40.1 & 56.7 & 0.7 \\
\hline & Other Food & 7.0 & $<0.1$ & $<0.1$ \\
\hline \multirow{6}{*}{$\begin{array}{l}\text { John Day forebay } \\
(269,301\end{array}$} & Mollusca & 0.3 & to. 1 & to. 1 \\
\hline & Crustacea & 79.1 & 37.2 & 8.9 \\
\hline & Insecta & 31.2 & 1 & 2.0 \\
\hline & $\begin{array}{l}\text { Osteicthyes } \\
\text { Salmonidae }\end{array}$ & $\begin{array}{r}34.2 \\
4.0\end{array}$ & $\begin{array}{l}61.5 \\
12.1\end{array}$ & $\begin{array}{r}0.4 \\
<0.1\end{array}$ \\
\hline & Non-Salmonids & 30.2 & 49.4 & 0.4 \\
\hline & Other Food & 7.0 & $<0.1$ & $<0.1$ \\
\hline
\end{tabular}


Gastric evacuation experiments on smallmouth bass were completed in september 1986 and the results will be reported in the 1987 Annual Report.

Abundance and Distribution of Prey Fishes

Dominant prey fish species sampled during July, 1986 were generally similar to those of 1985 (Palmer et al. 1986). Largescale sucker and crappies dominated the catch at backwater areas, while sand roller and largescale sucker dominated at main channel locations (Table 10).

Variations in catch per seine haul indicated distibution patterns similar to those in 1985. Highest catches of largescale sucker, chinook salmon, and sand roller were near main channel locations in the upper reservoir and catches of bridgelip sucker and chislemouth were highest near shore at John Day forebay. Highest catches of spiny-ray prey fishes (sunfishes, crappies, and yellow perch) were observed at backwater locations in the upper reservoir.

Reach Seine Efficiency Experiments

Eighteen beach seine efficiency experiments were conducted during April, May, June, and August, 1986; eight over a sand substrate and ten over a mixed sand-gravel-cobble substrate. These data were combined with data collected during 1985 to improve the mean efficiency estimates. 
Table 10. Total catch and catch per haul (in parentheses) of prey fish (< $250 \mathbf{m m}$ fL) collected with a beach seine at all sampling locations in John Day Reservoir, July, 1986.

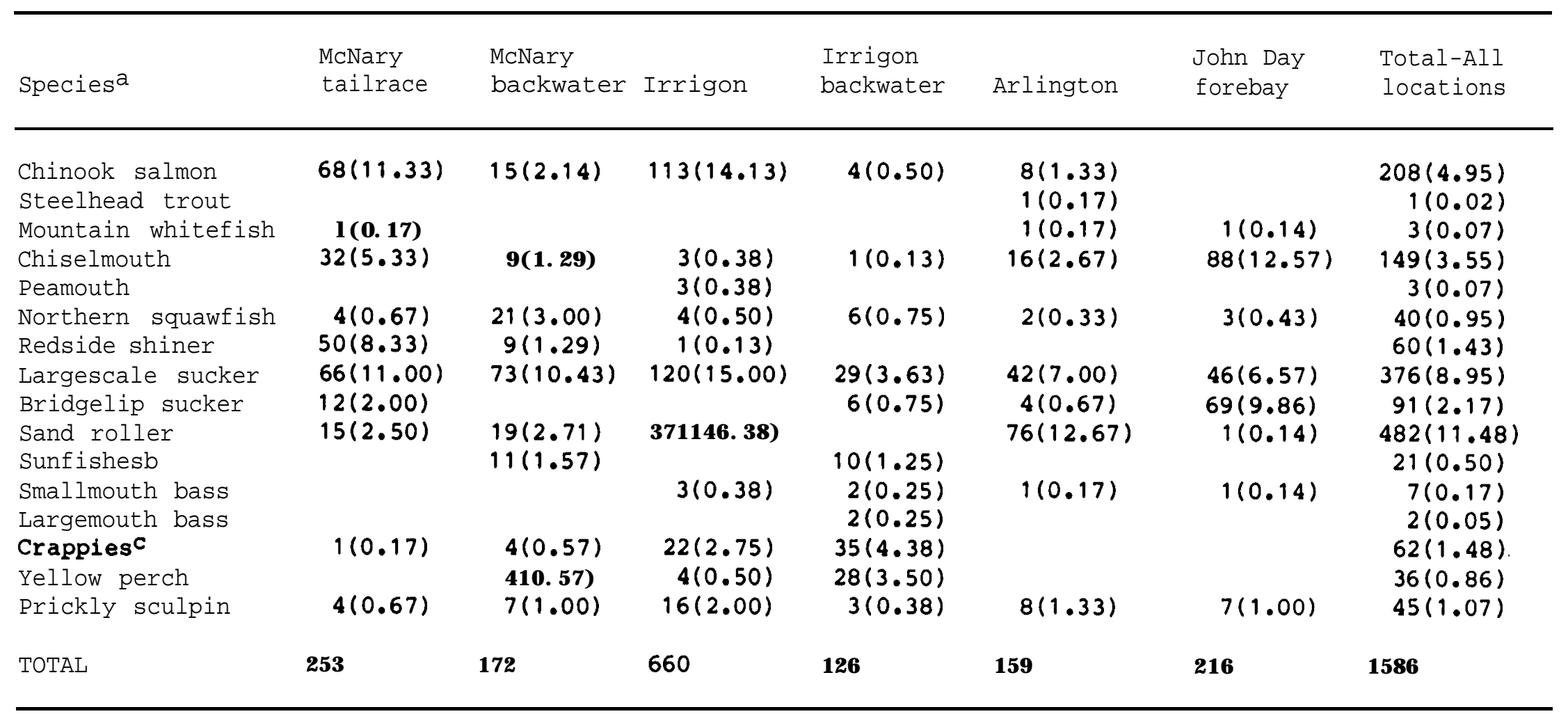

a Scientific names for all common names are given in Appendix Table 6 .

b Includes pumpkinseed and bluegill.

c Includes white crappie and black crappie. 
Seine efficiencies for chinook salmon, suckers (Catostomus spp.), crappies (Pomoxis spp.) and prickly sculpin significantly differed $(\mathrm{P}<0.05)$ over the two substrates (Table 11). The hypothesis of equal efficiency for each substrate could not be rejected for chiselmouth, northern squawfish, sand roller, sunfishes (Lepomis spp.), smallmouth bass, and yellow perch. Therefore, a weighted mean efficiency estimate was calculated for these species. An efficiency estimate over a coarse substrate was not obtained for American shad, peamouth, brown bullhead, and largemouth bass (Table 11).

Some prey taxa are more vulnerable to capture by seining than others. The weighted mean percent efficiency estimates for chiselmouth and northern squawfish were $>70 \%$, indicating a high vulnerability to capture, as were the estimates for chinook salmon, peamouth, and suckers when these species were captured over a fine substrate and crappies captured over either substrate. Sand roller, sunfishes, smallmouth bass, and yellow perch were moderately vulnerable to capture, efficiency estimates ranging from 40 to $70 \%$ Chinook salmon and suckers captured over a coarse substrate were also moderately vulnerable with efficiency estimates of 56.6 and $47.7 \%$, respectively. Prickly sculpin captured over either substrate and American shad and brown bullhead captured over fine substrates were least vulnerable to capture with efficiency estimates of less than $37 \%$. 
Table 11. Mean percent seine efficiency and 95\% confidence intervals (C.I.) for prey taxa captured over fine (sand) and coarse (sand-gravel-cobble) substrates in John Day Reservoir, 1985 and 1986. The results are back-transformed from normalized data. Where no significant difference (t-test, $\mathrm{P}<0.05)$ exists between efficiency estimates for fine and coarse substrates, a weighted mean 0 efficiency was calculated.

\begin{tabular}{|c|c|c|c|c|c|c|c|c|}
\hline \multirow[b]{2}{*}{ Prey taxa } & \multicolumn{3}{|c|}{$\begin{array}{c}\text { Fine } \\
\text { Substrate }\end{array}$} & \multicolumn{3}{|c|}{$\begin{array}{l}\text { Coarse } \\
\text { Substrate }\end{array}$} & \multicolumn{2}{|l|}{$\begin{array}{l}\text { Substrates } \\
\text { Combined }\end{array}$} \\
\hline & $\begin{array}{c}\text { Mean } \frac{0}{0} \\
\text { efficiency }\end{array}$ & $\begin{array}{l}95 \% \\
\text { C.I. }\end{array}$ & $\begin{array}{c}\# \text { of } \\
\text { estimates }\end{array}$ & $\begin{array}{c}\text { Mean } \% \\
\text { efficiency }\end{array}$ & $\begin{array}{l}95 \% \\
\text { C.I. }\end{array}$ & $\begin{array}{c}\# \text { of } \\
\text { estimates }\end{array}$ & $\begin{array}{l}\text { Weighted } \\
\text { Mean \% } \\
\text { efficiency }\end{array}$ & $\begin{array}{l}95 \% \\
\text { C.I. }\end{array}$ \\
\hline American shad & 36.1 & 20.9 & 6 & & & & & - \\
\hline chinook salmon & 84. 2 & 27.4 & 9 & 56.6 & 15. 7 & 11 & $\star$ & \\
\hline chiselmouth & 91.5 & 31.4 & 4 & 73. 6 & 25.2 & 11 & 78.4 & 18. 7 \\
\hline peamouth & 95.7 & 15. 5 & 12 & & & & & \\
\hline northern squawfish & 85. 1 & 19. 7 & 13 & 87.5 & 52.1 & 4 & 85. 7 & 16. 6 \\
\hline suckersb & 76. 7 & 20.1 & 16 & 47. 7 & 20.6 & 14 & $*$ & \\
\hline brown bullhead & 35.8 & 27.6 & 6 & & & & & \\
\hline sand roller & 46. 6 & 22.2 & 14 & 30.6 & 31.0 & 6 & 41.8 & 16. 7 \\
\hline sunfishes ${ }^{C}$ & 58. 3 & 44. 7 & 6 & 65.1 & 7.4 & 3 & 60.6 & 27.7 \\
\hline smallmouth bass & 59.7 & 36. 3 & 7 & 28. 7 & 29.4 & 5 & 46. 8 & 21. 4 \\
\hline largemouth bass & 41.6 & 18. 6 & 6 & & & & - & \\
\hline crappies $^{\mathrm{d}}$ & 74. 3 & 13. 3 & 6 & 90.5 & 49.4 & 3 & $\star$ & \\
\hline yellow perch & 51.9 & 25.8 & 13 & 35.2 & 40.4 & 4 & 48. 0 & 20.1 \\
\hline prickly sculpin & 30. 4 & 13. 8 & 14 & 13. 4 & 5. 0 & 15 & $*$ & \\
\hline
\end{tabular}

a Scientific names for all common names are given in Appendix Table 6.

b Includes largescale sucker and bridgelip sucker.

c Includes bluegill and pumpkinseed.

d Includes black crappie and white crappie.

* A significant difference (t-test, $\mathrm{P}<0.05$ ) exists between the mean efficience estimates for the two substrates.

- Insufficient data were collected to obtain a mean $\frac{\circ}{0}$ efficiency. 
Consumption Estimates

Daily consumption estimates of juvenile salmonids by northern squawfish are presented in Table 12 for all years combined (individual years are in Appendix Tables 7-9). Peaks in salmonid consumption occurred, during May and July which correspond to the temporal peaks of juvenile salmonid out-migration past McNary Dam. The consumption rate of salmonids is much greater during July than any other month, especially in the McNary RZ where the highest overall estimate of 5.8 salmonids per predator (about 6\%) ration was observed during 1985.

The consumption of salmonids by walleye was variable by month and years (Table 13), however a general increase was observed during the juvenile salmonid migration season. Data are missing in July due to both the sampling schedule and the distribution and behavior of the species. This precluded estimating the overall seasonal mean consumption rate for walleye. The analysis of the pooled data set (1983-1985) i ndicates a maximum ration of about $1.4 \mathrm{mg}$ salmonids/g walleye during May and August. Total consumption of all preyfish by walleye also varied by month with minimum rates in April and subsequent increases (Table 13). Maximum consumption rate in John Day Reservoir was observed during June and August, varying by year.

$$
\text { Preliminary estimates of daily consumption rates of juvenile }
$$

salmonids by smallmouth bass for all years combined indicate that predation by this species is very low (Table 14). Similar to walleye, few smallmouth bass were taken in the McNary RZ and few salmonids were consumed. Monthly estimates of daily consumption of salmonids per 
Table 12. Daily consumption estimates of juvenile salmonids and total prey fish by northern squawfish ( $\mathrm{n}=3,099)$ in John Day Reservoir during 1983-1985; stratified by month for McNary tailrace restricted zone versus the remainder of the reservoir.

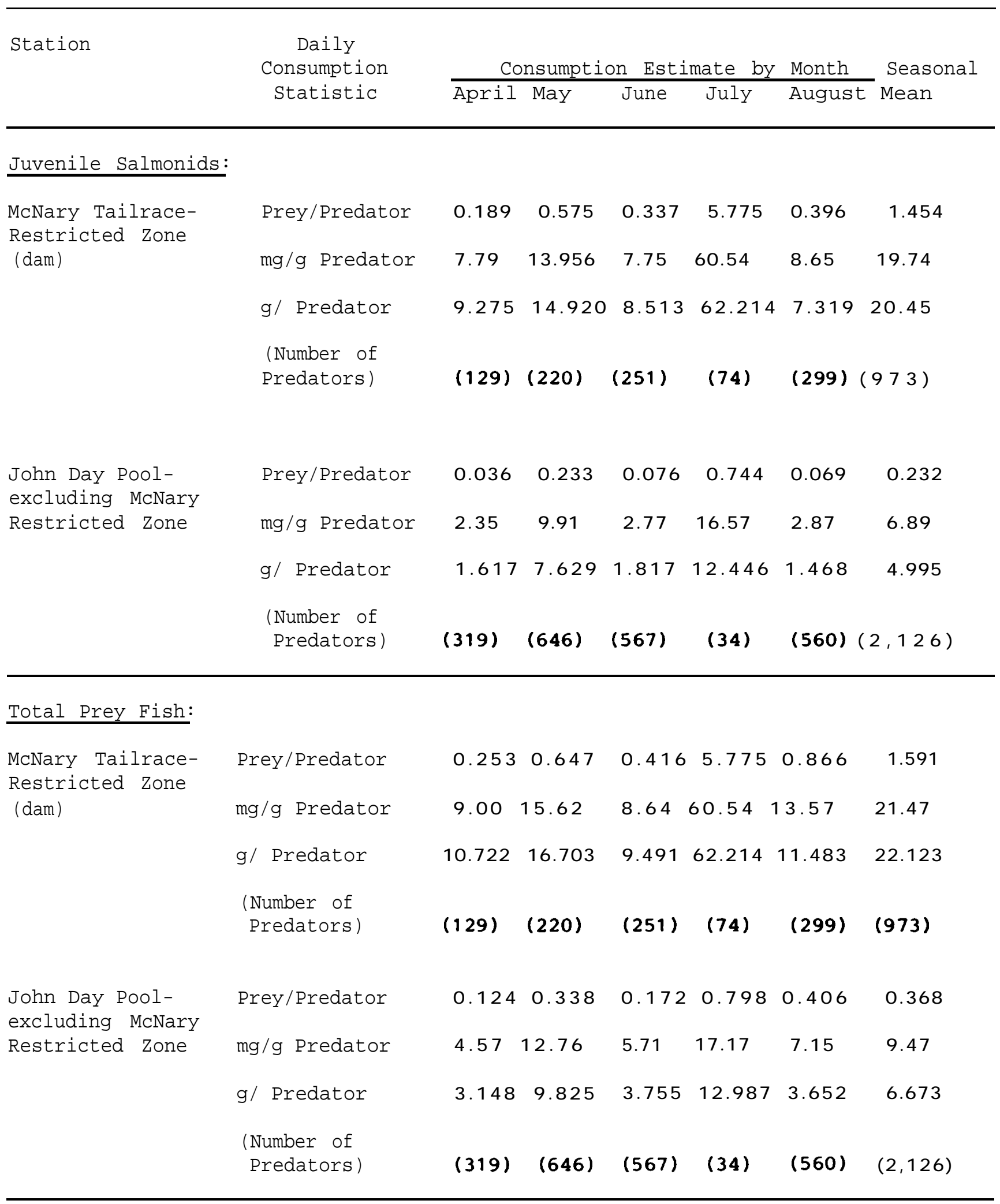


Table 13. Daily consumption estimates of juvenile salmonids (total prey fish in parentheses) by walleye in John Day Reservoir during 1983-1985; stratified by month.

\begin{tabular}{|c|c|c|c|c|c|c|}
\hline \multirow[t]{2}{*}{ Year } & \multirow{2}{*}{$\begin{array}{c}\text { Daily } \\
\text { Consumption } \\
\text { Statistic }\end{array}$} & \multicolumn{2}{|c|}{ Consumption } & Estimate & \multicolumn{2}{|c|}{ by Month } \\
\hline & & April & May & June & - & August \\
\hline \multirow[t]{2}{*}{1983} & Prey/Predator & $\begin{array}{c}0.015 \\
(0.239)\end{array}$ & $\begin{array}{l}0.063 \\
(0.693)\end{array}$ & $\begin{array}{l}0.193 \\
(1.085)\end{array}$ & & $\begin{array}{c}0.153 \\
(0.482)\end{array}$ \\
\hline & $\mathrm{mg} / \mathrm{g}$ Predator & $\begin{array}{c}0.12 \\
(2.23)\end{array}$ & $\begin{array}{c}0.44 \\
(3.97)\end{array}$ & $\begin{array}{c}0.28 \\
(8.77)\end{array}$ & & $\begin{array}{c}0.90 \\
(4.40)\end{array}$ \\
\hline \multirow[t]{2}{*}{1984} & Prey/Predator & $\begin{array}{c}0.034 \\
(0.2831\end{array}$ & $\begin{array}{l}0.277 \\
(1.137)\end{array}$ & $\begin{array}{c}0.131 \\
(1.796)\end{array}$ & & $\begin{array}{c}0.543 \\
(2.936)\end{array}$ \\
\hline & $\mathrm{mg} / \mathrm{g}$ Predator & $\begin{array}{c}0.29 \\
(2.66)\end{array}$ & $\begin{array}{c}3.50 \\
11.62) \quad(1\end{array}$ & $\begin{array}{c}0.73 \\
16.16)\end{array}$ & & $\begin{array}{c}3.98 \\
(15.55)\end{array}$ \\
\hline \multirow[t]{2}{*}{1985} & Prey/Predator & $\begin{array}{l}0 \\
(0.053)\end{array}$ & $\begin{array}{c}0.058 \\
(0.462)\end{array}$ & $\begin{array}{c}0.058 \\
(2.461)\end{array}$ & & $\begin{array}{l}0 \\
(2.293)\end{array}$ \\
\hline & $\mathrm{mg} / \mathrm{g}$ Predator & $\begin{array}{l}0 \\
(0.14\end{array}$ & $\begin{array}{l}0.96 \\
(5.02) \quad(2\end{array}$ & $\begin{array}{c}0.07 \\
23.55)\end{array}$ & & $\begin{array}{c}0 \\
(27.22)\end{array}$ \\
\hline \multirow[t]{2}{*}{$\begin{array}{l}\text { 1983-1985 } \\
\text { (data pooled) }\end{array}$} & Prey/Predator & $\begin{array}{l}0.020 \\
(0.208)\end{array}$ & $\begin{array}{l}0.112 \\
\quad(0.698\end{array}$ & $\begin{array}{l}0.118 \\
3) \quad(1.550)\end{array}$ & $\begin{array}{l}- \\
-\end{array}$ & $\begin{array}{c}0.218 \\
(1.204)\end{array}$ \\
\hline & $\mathrm{mg} / \mathrm{g}$ Predator & $\begin{array}{l}0.17 \\
(1.76)\end{array}$ & $\begin{array}{l}1.40 \\
(6.13)\end{array}$ & $\begin{array}{l}0.39 \\
(13.81)\end{array}$ & $\begin{array}{l}- \\
-\end{array}$ & $\begin{array}{c}1.37 \\
(9.48)\end{array}$ \\
\hline
\end{tabular}


Table 14. Daily consumption estimates of juvenile salmonid smolts and total preyfish by smallmouth bass $(\mathrm{n}=3,846)$ in John Day Reservoir during 1983-1985; stratified by month for McNary tailrace restricted zone versus the remainder of the reservoir.

Station

Daily

Consumption

Statistic

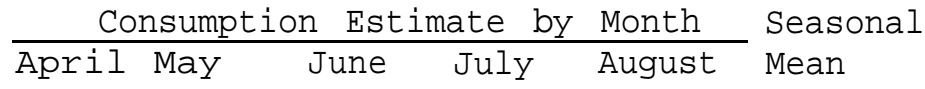

Juvenile Salmonids:

\begin{tabular}{|c|c|c|c|c|c|c|c|}
\hline \multirow{2}{*}{$\begin{array}{l}\text { McNary Tailrace- } \\
\text { Restricted Zone } \\
\text { (dam) }\end{array}$} & Prey/Predator & 0 & 0 & \multicolumn{2}{|l|}{0} & 1.647 & 0.041 \\
\hline & $\mathrm{mg} / \mathrm{g}$ Predator & 0 & 0 & 0 & & 0.91 & 0.23 \\
\hline & g/ Predator & 0 & 0 & 0 & & 0.433 & 0.108 \\
\hline & $\begin{array}{l}\text { (Number of } \\
\text { Predators) }\end{array}$ & $(2)$ & (9) & (6) & (0) & (4) & $(21)$ \\
\hline $\begin{array}{l}\text { John Day Pool- } \\
\text { excluding McNary }\end{array}$ & Prey/Predator & 0.002 & .009 & 0.021 & 0.041 & 0.039 & 0.022 \\
\hline Restricted Zone & $\mathrm{mg} / \mathrm{g}$ Predator & 0.003 & 0.04 & 0.27 & 3.07 & 1.84 & 1.05 \\
\hline & g/ Predator & 0.002 & 0.013 & 0.074 & 0.523 & 0.473 & 0.217 \\
\hline & $\begin{array}{l}\text { (Number of } \\
\text { Predators) }\end{array}$ & $(370)$ & $(1054)$ & (1281) & (167) & (953) & (3825) \\
\hline
\end{tabular}

Total Prey Fish:

\begin{tabular}{|c|c|c|c|c|c|c|c|}
\hline \multirow{2}{*}{$\begin{array}{l}\text { McNary Tailrace- } \\
\text { Restricted Zone } \\
\text { (dam) }\end{array}$} & Prey/Predator & 0.606 & 0.256 & 0.157 & - & 3.294 & 1.078 \\
\hline & $\mathrm{mg} / \mathrm{g}$ Predator & 3.13 & 3.42 & 0.88 & - & 1.58 & 2.25 \\
\hline \multirow{4}{*}{$\begin{array}{l}\text { John Day Pool- } \\
\text { excluding McNary } \\
\text { Restricted Zone }\end{array}$} & g/ Predator & 4.184 & 1.741 & 0.388 & - & 0.752 & 1.766 \\
\hline & $\begin{array}{l}\text { (Number of } \\
\text { Predators) }\end{array}$ & (2) & (9) & (6) & (0) & (4) & (21) \\
\hline & Prey/Predator & 0.245 & 0.366 & 0.652 & 1.302 & 1.545 & 0.822 \\
\hline & mg/g Predator & 4.82 & 8.47 & 17.64 & 60.08 & 36.18 & 25.44 \\
\hline & g/ Predator & 2.462 & 2.760 & 0.652 & 10.253 & 9.319 & 5.089 \\
\hline & $\begin{array}{l}\text { (Number of } \\
\text { Predators) }\end{array}$ & $(370)$ & (1054) & $(1281)$ & (167) & (953) & (3825) \\
\hline
\end{tabular}


predator in John Day Reservoir exclusive of the McNary Rz were always less than 0.04 salmonids per day. The highest salmonid consumption generally occurred during August (Appendix Tables 10-12) .

Total prey fish consumption rates of smallmouth bass were comparable to those of squawfish (mean monthly daily ration ranged from about 0.26 to 7.6 percent predator body weight per day). The maximum monthly consumption of prey fish usually occurred in August.

Ristopathology of Juvenile Salmonids

Thirty-one freshly ingested juvenile salmonids were removed from stomachs of northern squawfish and channel catfish collected in the McNary tailrace RZ and 162 juvenile salmonids were collected from the river. Twenty-six of the freshly ingested salmonids were chinook salmon and five were steelhead trout. Fork lengths of chinook salmon and steelhead collected ranged from 101 to $172 \mathrm{~mm}$ and 135 to $202 \mathrm{~mm}$, respectively. All freshly ingested salmonids and a sub-sample of juvenile salmonids collected from the river are currently being analyzed by the National Fishery Research Center in Seattle.

\section{DISCUSSION}

The abundance and composition of prey items in the diets of northern squawfish, walleye, and smallmouth basss in 1986 were generally similar to those in other years. 
Salmonids were the single most important food item of northern squawfish at McNary tailrace during all sampling periods every year. Similar to results in 1984 and 1985, positive relationships between northern squawfish length and piscivory were also found as fish comprised a greater proportion of the weight of food items in the diet of larger predators; no fish were found in the stomachs of northern squawfish less than $100 \mathrm{~mm}$ in length.

In July 1986 the percent weight of salmonids in the diet of walleye (23.7\%) was higher than in any month during previous years, although the sample size was low. Catches of walleye were highest every year at McNary tailrace and Irrigon, low at Arlington, and only one was caught at John Day forebay. Fish have accounted for nearly all of the food (by weight) consumed by walleye every year studied.

As in prevous years, juvenile salmonids contributed little to the diet of smallmouth bass. Percent weight of salmonids in the diet was greatest at Mcnary tailrace and at Irrigon in most years. Fish decreased in the diet in the lower portion of the reservoir (Arlington and John Day forebay) whereas crayfish increased.

Composition of prey taxa in beach seine catches in July 1986 was generally similar to other years with largescale sucker, sand roller, and chinook salmon dominating the catch. Total catch of prey fishes was highest at Irrigon due to the large number of sand roller taken there.

Results of beach seine efficiency studies conducted in 1985 and 1986 suggest that seine efficiency differs among prey species and is 
influenced by substrate type. Chiselmouth, crappies and northern squawfish were very vulnerable to capture over both substrates; chinook salmon, peamouth, and suckers were very vulnerable over only fine substrates; sand roller, sunfishes, smallmouth bass, and yellow perch were moderately vulnerable over both substrates, and prickly sculpin, American shad, and brown bullhead were least vulnerable to capture. Preliminary estimates of consumption rates of juvenile salmonids have been completed for walleye, northern squawfish and smallmouth bass, 1983-1985. These data are prerequisite for estimating losses of juvenile salmonids to predators in the system and for the predation dynamics feeding ecology model which is being developed jointly by USFWS and ODFW. Daily salmonid consumption rate estimates per predator were relatively high for northern squawfish, moderate for walleye, and low for smallmouth bass. Maximum daily consumption rates of 4.9 salmonids/predator (1985) and 5.8 salmonids/predator (1983-1985 pooled) which we estimated are comparable to the maximum mean value of 5.8 salmonids/predator/day observed for Sacramento squawfish (P. grandis) at the Red Bluff diversion dam (Vondracek and Moyle 1983). The total daily rations estimated for predators in John Day Reservoir are generally consistent with values documented in the literature for predacious fishes; i.e., from 0.5 to $6.0 \%$ body weight per day (Swenson and Smith 1976; Keast and Walsh 1968; Thorpe 1977; Seaburg and Moyle 1976; Lane et al. 1979; Brett et al. 1969). 
On an areal basis, salmonid consumption by northern squawish is highest at the McNary Dam tailrace RZ, in contrast to the other two predator species which exhibit negligible impact there. On a temporal basis the highest consumption rates occur June-August with a pronounced maximum for northern squawfish in July. 


\section{Literature Cited}

Beyer, J.M., G. Lucchetti, and G. Gray. 1987. Gastric evacuation in northern squawfish (Ptychocheilus oregonensis). Can. J. Fish. and Aquatic Sciences (accepted for publication).

Brett, J.F., J.E. Shelhourn, and R. Shoop. 1969. Growth rate and body composition of fingerling sockeye salmon, Onchorhynchus nerka, in relation to temperature and ration size. J. Fish. Res. Board. Can. 26: 2363-2394.

Gray, G.A., D.E. Palmer, B.L. Hilton, P.J. Connolly, H.C. Hansel, J.M. Beyer, and G.M. sonnevil. 1984. Feeding activity, rate of consumption, daily ration and prey selection of major predators in the John Day Pool. Annual Report (1983) to the Bonneville Power Administration. National Fishery Research Center, Cook, Washington. 65 PP.

Gray, G.A., D.E. Palmer, B.L. Hilton, P.J. Connolly, H.C. Hansel, and J.M. Beyer. 1986 Section I. Feeding activity, rate of consumption, daily ration and prey selection of major predators in the John Day Reservoir. Annual Report (1984) to the Bonneville Power

Administration. National Fishery Research center, Cook, Washington. $162 \mathrm{pp}$. Portland, OR.

Holling, C.S. 1959. The components of predation as revealed by a study of small mammal predation of the European pine sawfly. Can. Entomol. 91: 293-230. 
Keast, A. and L. Walsh. 1968. Daily feeding p-eriodicities, food uptake rates, and dietary changes with hour of day in some lake fishes. J. Fish. Res. Bd. Can. 25(6): 1133-1144.

Palmer, D.E., H.C. Hansel, J.M. Beyer, S.C. Vigg, W.T. Yasutake, P.T. Lofy, S.D. Duke, M.J. Parsley, M.G. Mesa, L.A. Prendergast, R. Burkhardt, C. Burley, D.W. Eib, and T.P. Poe. 1986. Feeding activity, rate of consumption, daily ration and prey selection of major predators in John Day Reservoir, 1985. Annual Report to Bonneville Power Administration. National Fishery Research Center, Cook, Washington. $105 \mathrm{pp}$.

SAS Institute, Inc. 1985. SAS User's Guide: Statistics, Version 5 Edition. SAS Institute Inc., Cary, NC. 956 pp.

Seaburg, K.G. and P.B. Moyle. 1964. Feeding habits, digestive rates, and growth of some Minnesota warmwater fishes. Trans. Am. Fish. Soc. 93: 269-285.

Swenson, W.A. 1972. Food competition between walleye, Stitzostedion vitreum vitreum (Mitchell), and sauger, Stitzostedion canadense (Smith), in Lake of the Woods, Minnesota. Ph.D. Dissertation, University of Minnesota, $151 \mathrm{pp}$.

Swenson, W.A. and L.L. Smith. 1976. Influence of food competition, predation, and cannibalism on walleye (Stizostedion vitreum

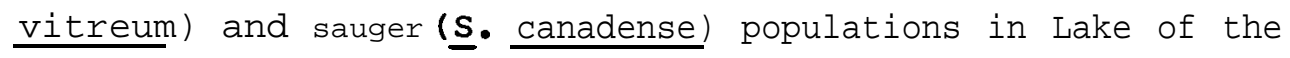
woods, Minnesota. J. Fish. Res. Bd. Can. 33: 1946-1954. 
Thorpe, J.E. 1977. Daily ration of adult perch, Perch fluviatilis

L. during the summer in Lock leven, Scotland. J. Fish. Biol.

11: $55-68$.

Vondracek, B. and P.B. Moyle. 1983. Squawfish predation at Red Bluff Diversion Dam. Contract Report for California Department of Water Resources. $34 \mathrm{PP}$.

Wahl, D.H. and L.A. Nielsen. 1985. Feeding ecology of the sauger (Stizostedion canadense) in a large river. Canadian Journal of Fish. and Aquat. Sci. 42: 120-128.

Zar, J.H. 1974. Biostatistical Analysis. Prentice-Hall, Inc., Englewood Cliffs, N.J. 620 pp. 
APPENDIX 


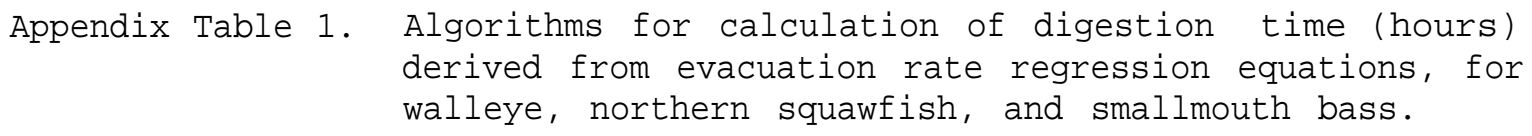

Walleye:

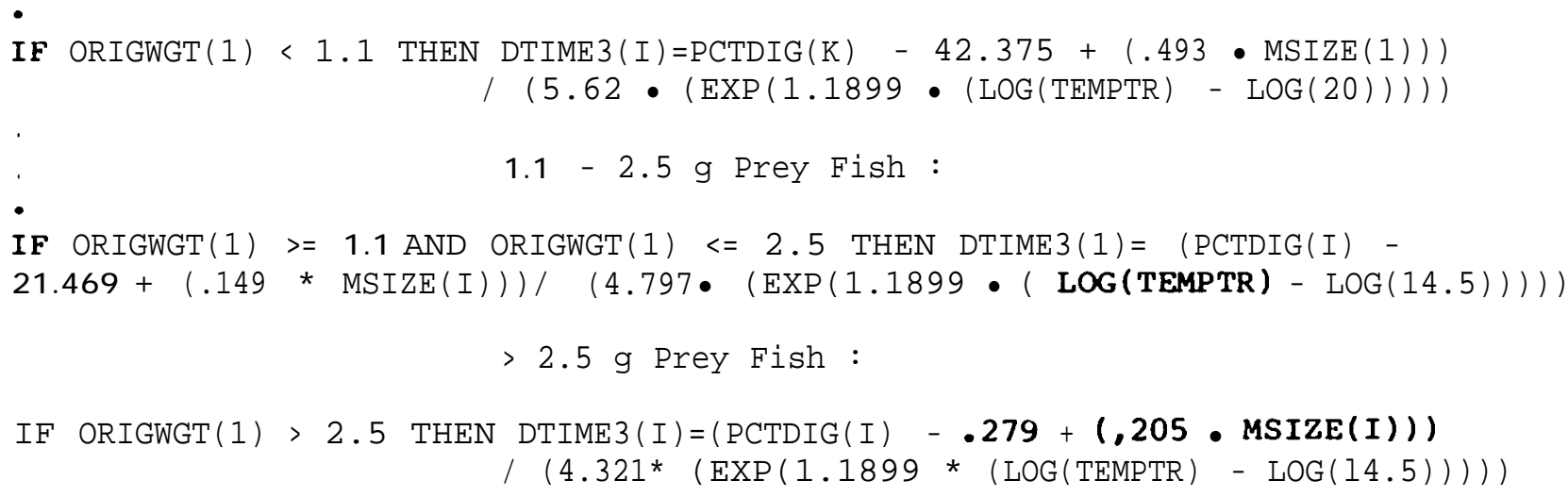


Appendix Table 2. Algorithms for 90\% digestion time (hours) derived from evacuation rate regression equations, for walleye, northern squawfish, and smallmouth bass.

Walleye:

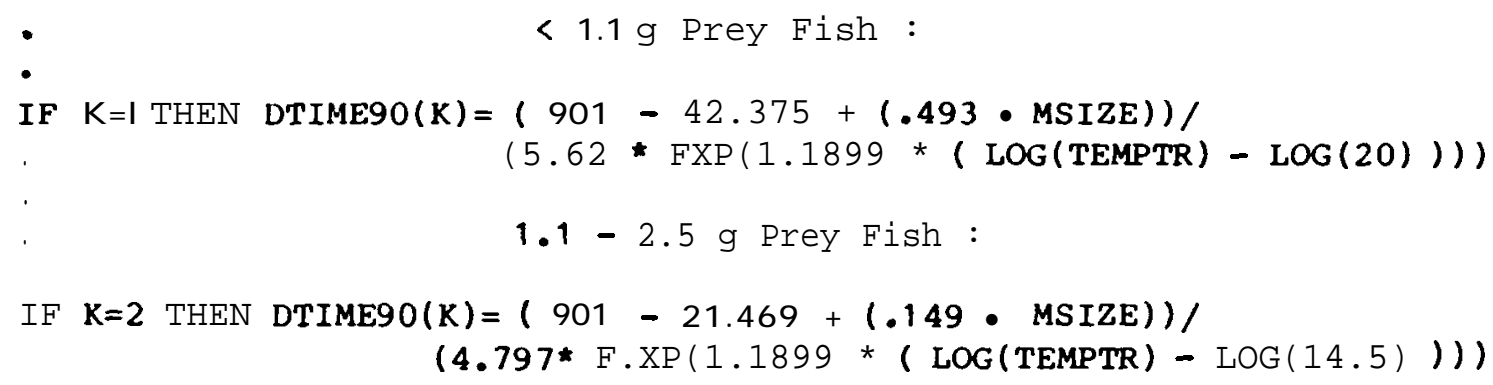

Northern Squawfish:

FOR $\mathrm{K}=1$ 'IO 11

- 


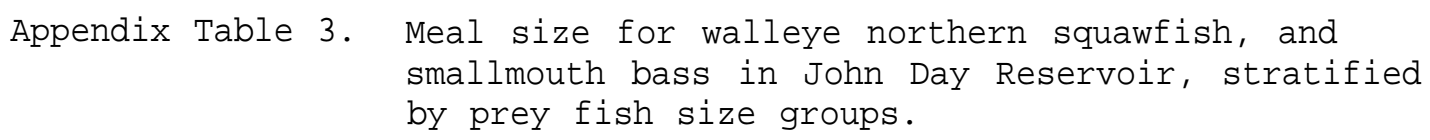

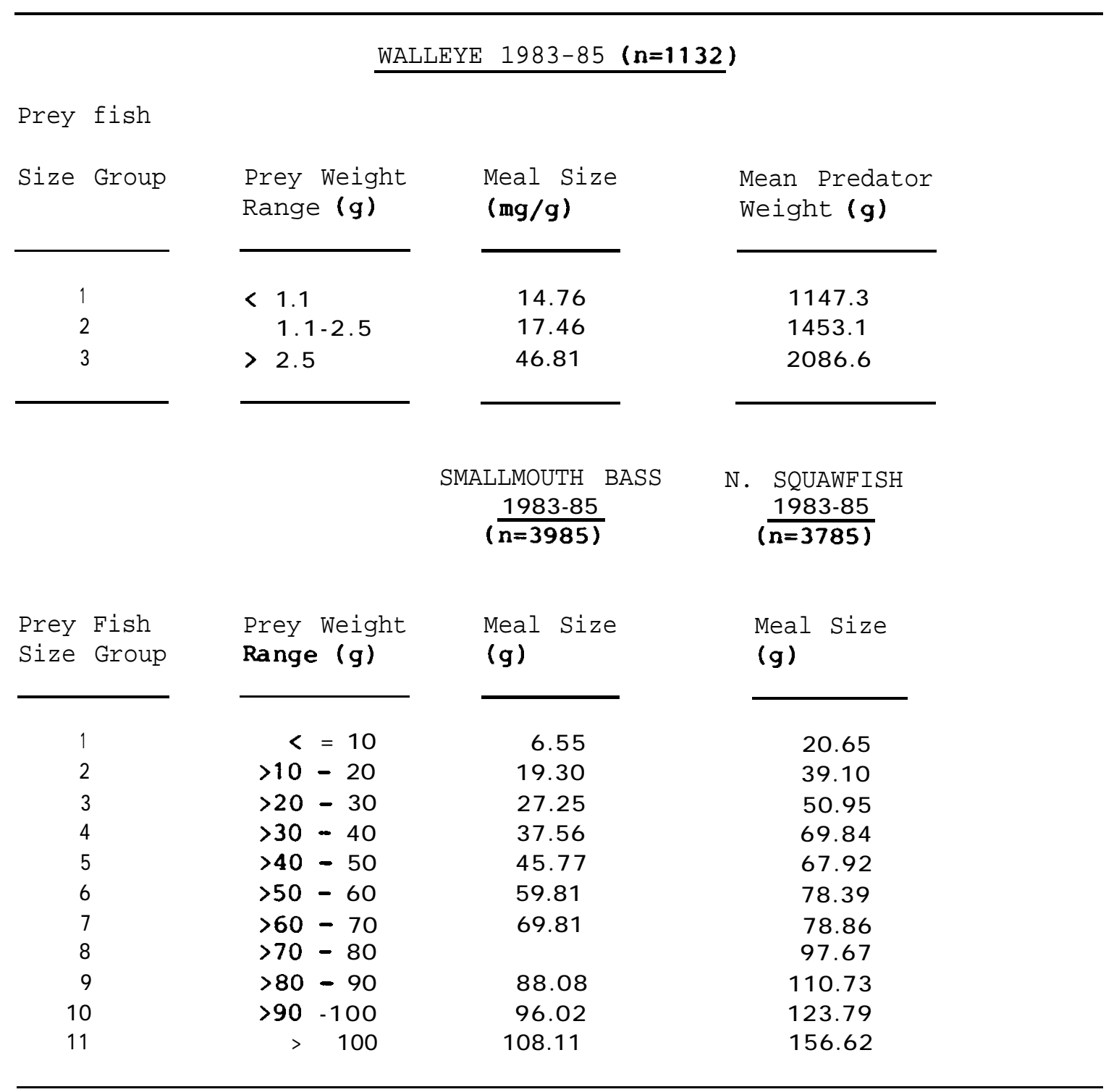




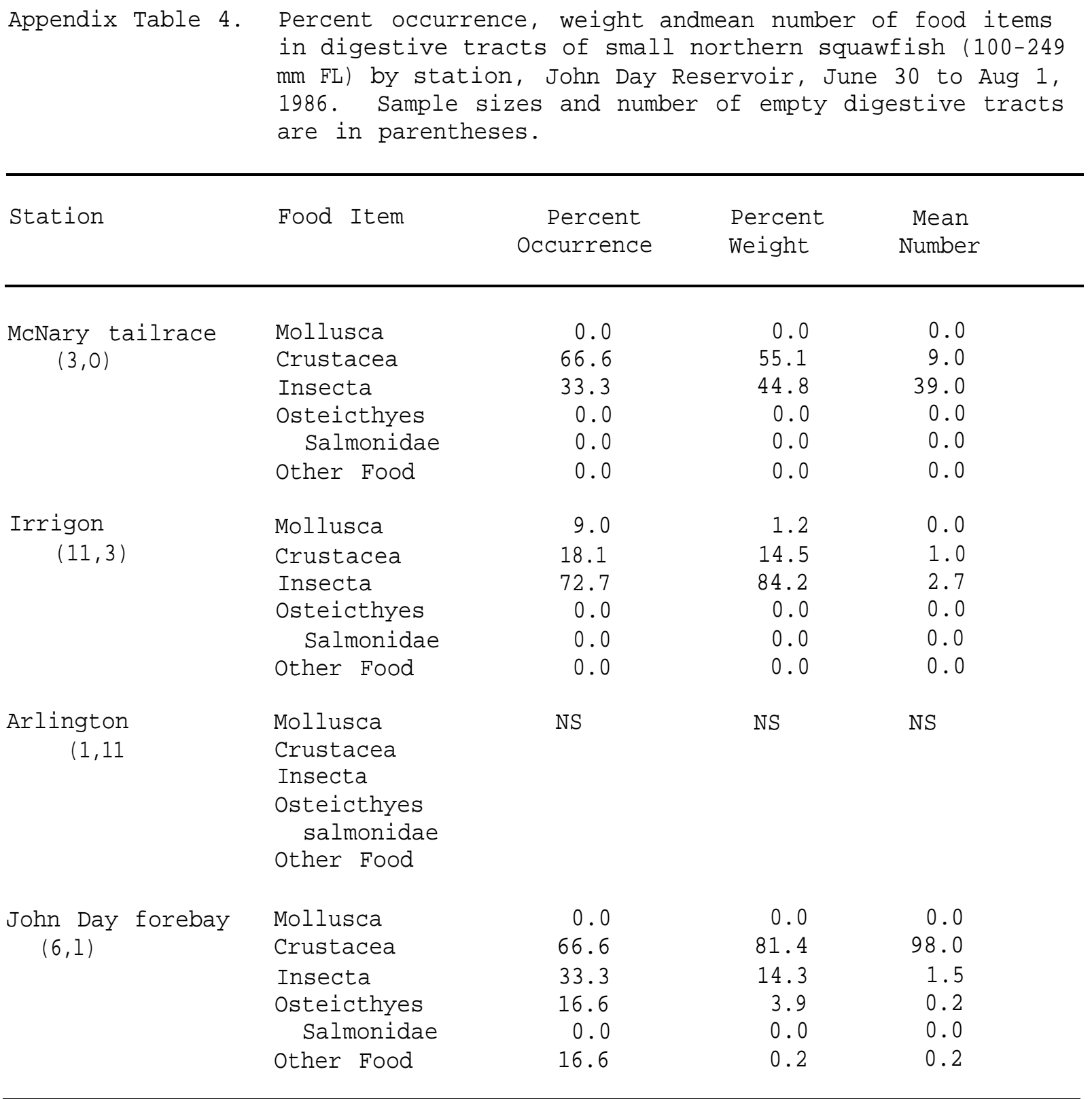

NS = No sample. 
Appendix Table 5. Percent occurrence, weight and mean number of food items in digestive tracts of small northern squawfish (100-249 mm FL) by sample period from McNary Tailrace, John day Reservoir, 1986. Sample sizes and number of empty digestive tracts are in parentheses.

\begin{tabular}{|c|c|c|c|c|}
\hline Date & Food Item & $\begin{array}{c}\text { Percent } \\
\text { Occurrence }\end{array}$ & $\begin{array}{l}\text { Percent } \\
\text { Weight }\end{array}$ & $\begin{array}{l}\text { Mean } \\
\text { Number }\end{array}$ \\
\hline \multirow{6}{*}{$\begin{array}{l}\text { Apr } 1 \text { - May } 1 \\
(2,2)\end{array}$} & Mollusca & 0.0 & 0.0 & 0.0 \\
\hline & Crustacea & 100.0 & 17.0 & 9.0 \\
\hline & Insecta & 100.0 & 16.5 & 1.0 \\
\hline & Osteicthyes & 0.0 & 0.0 & 0.0 \\
\hline & Salmonidae & 0.0 & 0.0 & 0.0 \\
\hline & Other Food & 100.0 & 66.3 & 1.0 \\
\hline \multirow{6}{*}{$\begin{array}{c}\text { May } 2-\text { May } 31 \\
(1,0)\end{array}$} & Mollusca & 0.0 & 0.0 & 0.0 \\
\hline & Crustacea & 0.0 & 0.0 & 0.0 \\
\hline & Insecta & 100.0 & 100.0 & 2.0 \\
\hline & Osteicthyes & 0.0 & 0.0 & 0.0 \\
\hline & Salmonidae & 0.0 & 0.0 & 0.0 \\
\hline & Other Food & 0.0 & 0.0 & 0.0 \\
\hline \multirow{5}{*}{$\begin{array}{l}\text { Jun } 1-\operatorname{Jun} 29 \\
(\mathbf{0}, \mathbf{0})\end{array}$} & Mollusca & NS & NS & NS \\
\hline & Crustacea & & & \\
\hline & Insecta & & & \\
\hline & $\begin{array}{l}\text { Osteicthyes } \\
\text { salmonidae }\end{array}$ & & & \\
\hline & Other Food & & & \\
\hline \multirow{6}{*}{$\begin{array}{l}\text { June } 30-\text { Aug } 1 \\
\qquad(3,0)\end{array}$} & Mollusca & 0.0 & 0.0 & 0.0 \\
\hline & Crustacea & 66.6 & 55.1 & 9.0 \\
\hline & Insecta & 33.3 & 44.8 & 39.0 \\
\hline & Osteicthyes & 0.0 & 0.0 & 0.0 \\
\hline & Salmonidae & 0.0 & 0.0 & 0.0 \\
\hline & Other Food & 0.0 & 0.0 & 0.0 \\
\hline
\end{tabular}

NS = No sample. 
Appendix Table 6. Common and scientific names of all prey fishes collected in 1985 and 1986.

\begin{tabular}{|c|c|}
\hline Common name & Scientific name \\
\hline American shad & Alosa sapidissma \\
\hline coho salmon & Oncorhynchus kisutch \\
\hline sockeye salmon & $\overline{\text { Oncorhynchus nerka }}$ \\
\hline chinook salmon & Oncorhynchus tshawytscha \\
\hline rainbow trout & Salmo gairdneri \\
\hline mountain whitefish & Prosopium williamsoni \\
\hline chiselmouth & $\overline{\text { Acrocheilus alutaceus }}$ \\
\hline carp & Cyprinus carpio \\
\hline peamouth & Mylocheilus caurinus \\
\hline northern squawfish & Ptychocheilus oregonensis \\
\hline speckled date & Rhinichthys osculus \\
\hline redside shiner & Richardsonius balteatus \\
\hline largescale sucker & Catostomus macrocheilus \\
\hline bridgelip sucker & Catostomus columbianus \\
\hline channel catfish & Ictalurus punctatus \\
\hline brown bullhead & Ictalurus nebulosus \\
\hline sand roller & Percopsis transmontana \\
\hline $\begin{array}{l}\text { threespine stickleback } \\
\text { sunfishes }\end{array}$ & $\begin{array}{l}\text { Gasterosteus aculeatus } \\
\text { Lepomis spp. }\end{array}$ \\
\hline smallmouth bass & Micropterus dolomieui \\
\hline largemouth bass & Micropterus salmoides \\
\hline crappies & Pomoxis spp. \\
\hline yellow perch & Perca flavescens \\
\hline walleye & Stizostedion vitreum vitreum \\
\hline prickly sculpin & Cottus asper \\
\hline
\end{tabular}


Appendix Table 7. Daily consumption estimates of juvenile salmonids and total preyfish by northern squawfish $(\mathrm{n}=970)$ in John Day Reservoir during 1983; stratified by month for McNary tailrace restricted zone versus the remainder of the reservoir.

\begin{tabular}{|c|c|c|c|c|c|c|}
\hline \multirow{3}{*}{$\begin{array}{l}\text { Species Group/ } \\
\text { Station } \\
\text { Juvenile Salmonids: }\end{array}$} & \multirow{2}{*}{$\begin{array}{c}\text { Daily } \\
\text { Consumption } \\
\text { Statistic }\end{array}$} & \multicolumn{4}{|c|}{ Consumption Estimate by } & \multirow{2}{*}{$\frac{\text { Month }}{\text { August }}$} \\
\hline & & $\overline{\text { April }}$ & May & June & July & \\
\hline & & & & & & \\
\hline \multirow{4}{*}{$\begin{array}{l}\text { McNary Tailrace- } \\
\text { Restricted Zone (dam) }\end{array}$} & Prey/Predator & & 0.484 & 0.757 & & 0.238 \\
\hline & $\mathrm{mg} / \mathrm{g}$ Predator & & 16.72 & 7.30 & & 5.90 \\
\hline & g/Predator & & 14.573 & 5.92 & & 3.921 \\
\hline & $\begin{array}{l}\text { (Number of } \\
\text { Predators) }\end{array}$ & (2) & (79) & $(65)$ & $(0)$ & $(94)$ \\
\hline \multirow{4}{*}{$\begin{array}{l}\text { John Day Pool- } \\
\text { excluding McNary } \\
\text { Restricted Zone }\end{array}$} & Prey/Predator & 0.037 & 0.323 & 0.097 & & 0.051 \\
\hline & mg/g Predator & 2.61 & 17.62 & 3.54 & & 2.04 \\
\hline & g/Predator & 1.626 & 13.013 & 1.852 & & 0.915 \\
\hline & $\begin{array}{l}\text { (Number of } \\
\text { Predators) }\end{array}$ & (197) & (209) & $(163)$ & (2) & (159) \\
\hline \multicolumn{7}{|l|}{ Total Prey Fish: } \\
\hline \multirow{4}{*}{$\begin{array}{l}\text { McNary Tailrace- } \\
\text { Restricted Zone (dam) }\end{array}$} & Prey/Predator & & 0.528 & 0.826 & - & 0.778 \\
\hline & $\mathrm{mg} / \mathrm{g}$ Predator & & 17.29 & 7.71 & - & 15.05 \\
\hline & g/Predator & & 15.076 & 6.258 & - & 9.996 \\
\hline & $\begin{array}{l}\text { (Number of } \\
\text { Predators) }\end{array}$ & (2) & $(79)$ & (65) & $(0)$ & $(94)$ \\
\hline \multirow{4}{*}{$\begin{array}{l}\text { John Day Pool- } \\
\text { excluding McNary } \\
\text { Restricted Zone }\end{array}$} & Prey/Predator & 0. 102 & 0.383 & 0.187 & - & 0.351 \\
\hline & mg/g Predator & 4.21 & 19.02 & 5.51 & - & 9.23 \\
\hline & g/Predator & 2.621 & 14.049 & 2.882 & - & 4.149 \\
\hline & $\begin{array}{l}\text { (Number of } \\
\text { Predators) }\end{array}$ & (197) & (209) & $(163)$ & (2) & (159) \\
\hline
\end{tabular}


Appendix Table 8. Daily consumption estimates of juvenile salmonids and total preyfish by northern squawfish $(\mathrm{n}=1,087)$ in John Day Reservoir during 1984; stratified by month for McNary tailrace restricted zone versus the remainder of the reservoir.

Species Group/
Station
Juvenile Salmonids:

McNary TailraceRestricted Zone (dam)

Daily Consumption Statistic \begin{tabular}{llll}
\multicolumn{2}{c}{ Consumption Estimate by } & Month \\
\hline April May June July & August
\end{tabular}

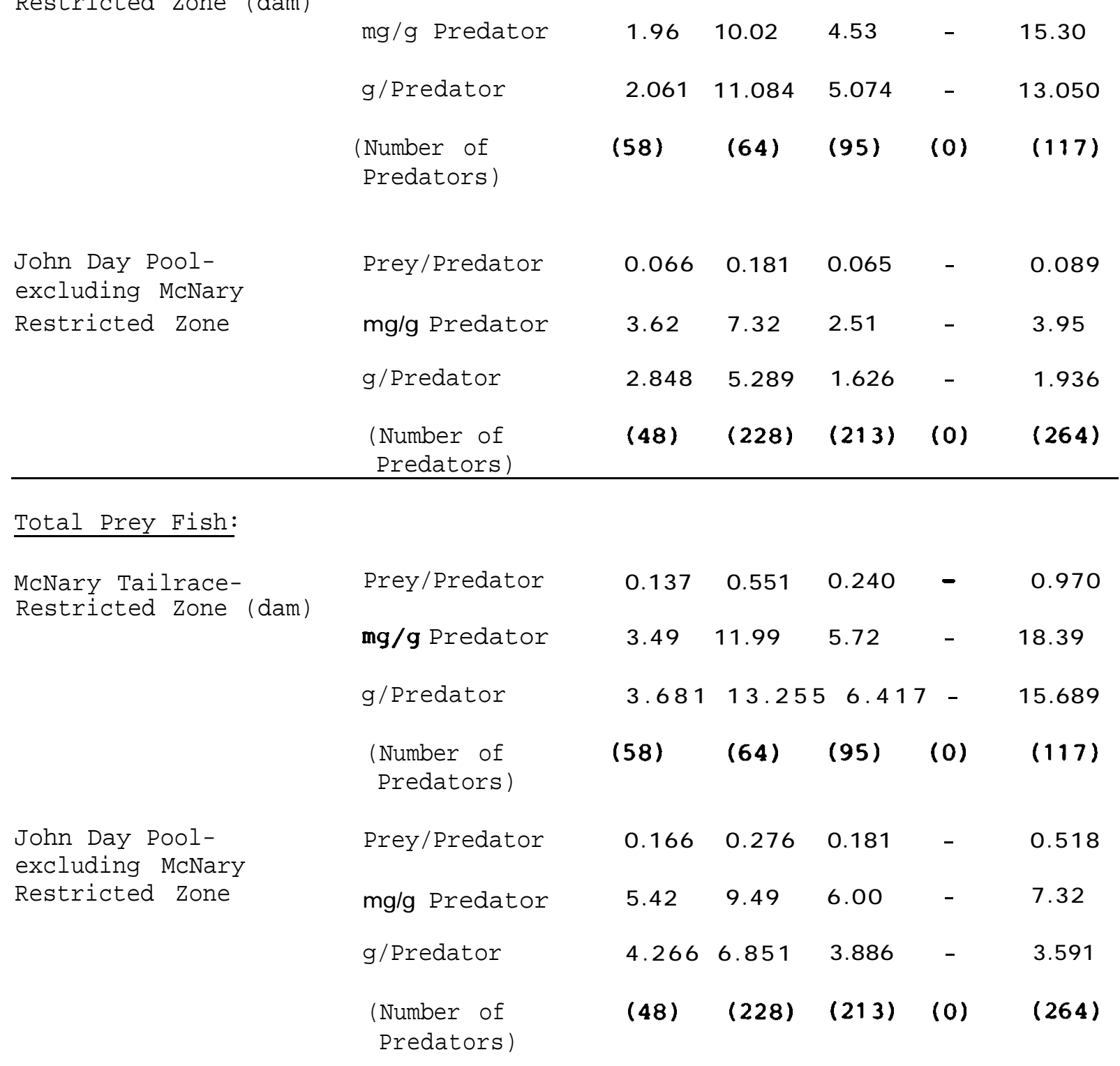


Appendix Table 9. Daily consumption estimates of juvenile salmonids and total preyfish by northern squawfish $(n=1,042)$ in John Day Reservoir during 1985; stratified by month for McNary tailrace restricted zone versus the remainder of the reservoir.

\begin{tabular}{|c|c|c|c|c|c|c|}
\hline \multirow{3}{*}{$\begin{array}{l}\text { Species Group/ } \\
\text { Station } \\
\text { Juvenile Salmonids: }\end{array}$} & \multirow{2}{*}{$\begin{array}{c}\text { Daily } \\
\text { Consumption } \\
\text { Statistic }\end{array}$} & \multicolumn{4}{|c|}{ Consumption Estimate by } & \multirow{2}{*}{$\frac{\text { Month }}{\text { August }}$} \\
\hline & & $\overline{\text { April }}$ & May & June & July & \\
\hline & & & & & & \\
\hline \multirow{4}{*}{$\begin{array}{l}\text { McNary Tailrace- } \\
\text { Restricted Zone (dam) }\end{array}$} & Prey/Predator & 0.306 & 0.733 & 0.536 & 4.878 & 0.230 \\
\hline & mg/g Predator & 11.81 & 14.70 & 12.57 & 51.14 & 3.00 \\
\hline & g/Predator & 15.536 & 18.267 & 16.064 & 52.552 & 3.097 \\
\hline & $\begin{array}{l}\text { (Number of } \\
\text { Predators) }\end{array}$ & (69) & $(77)$ & (91) & $(74)$ & (88) \\
\hline $\begin{array}{l}\text { John Day Pool- } \\
\text { excluding McNary }\end{array}$ & Prey/Predator & 0.013 & 0.185 & 0.080 & 0.805 & 0.056 \\
\hline \multirow[t]{3}{*}{ Restricted Zone } & mg/g Predator & 0.88 & 5.62 & 2.75 & 17.27 & 2.08 \\
\hline & g/Predator & 0.716 & 4.795 & 2.148 & 13.483 & 1.292 \\
\hline & $\begin{array}{l}\text { (Number of } \\
\text { Predators) }\end{array}$ & (74) & (209) & (191) & $(32)$ & $(137)$ \\
\hline
\end{tabular}

Total Prey Fish

McNary Tailrace-

Restricted Zone (dam)

John Day Poolexcluding McNary

Restricted Zone

$\begin{array}{lccccc}\text { Prey/Predator } & 0.363 & 0.837 & 0.621 & 4.878 & 0.983 \\ \text { mg/g Predator } & 12.78 & 16.85 & 13.43 & 51.14 & 7.75 \\ \text { g/Predator } & 16.808 & 20.939 & 17.161 & 52.552 & 7.990 \\ \begin{array}{l}\text { (Number of } \\ \text { Predators) }\end{array} & \mathbf{( 6 9 )} & \mathbf{( 7 7 )} & \mathbf{( 9 1 )} & \mathbf{( 7 4 )} & \mathbf{( 8 8 )} \\ & & & & & \end{array}$

Prey/Predator

0.156

0.333

0.154

0.862

0.238

$\mathrm{mg} / \mathrm{g}$ Predator

$4.77 \quad 10.29$

$5.61 \quad 17.85$

5.50

g/Predator

3.836

8.784

$4.386 \quad 13.936$

3.424

(Number of Predators)
(74) (209) (191) (32) (137) 


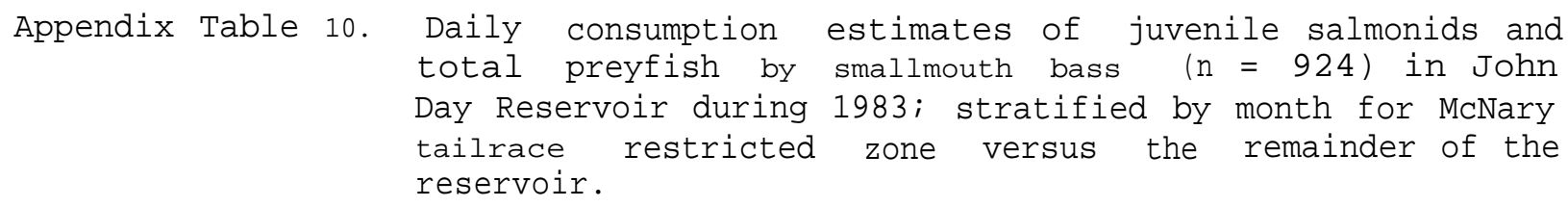

$\begin{array}{llll}\text { Species Group/ } & \text { Daily } & & \\ \text { Station } & \begin{array}{c}\text { Consumption } \\ \text { Statistic }\end{array} & \text { April May June July August }\end{array}$

Juvenile Salmonids:

\begin{tabular}{|c|c|c|c|c|c|c|}
\hline McNary Tailrace- & Prey/Predator & & 0 & - & & 0 \\
\hline & $\mathrm{mg} / \mathrm{g}$ Predator & & 0 & - & & 0 \\
\hline & g/Predator & & 0 & - & & 0 \\
\hline & $\begin{array}{l}\text { (Number of } \\
\text { Predators) }\end{array}$ & (0) & (6) & (0) & (0) & (1) \\
\hline $\begin{array}{l}\text { John Day Pool- } \\
\text { excluding McNary }\end{array}$ & Prey/Predator & 0 & 0.010 & 0.020 & 0 & 0.009 \\
\hline Restricted Zone & $\mathrm{mg} / \mathrm{g}$ Predator & 0 & 0.03 & 0.15 & 0 & 0.43 \\
\hline & g/Predator & 0 & 0.011 & 0.034 & 0 & 0.122 \\
\hline & $\begin{array}{l}\text { (Number of } \\
\text { Predators) }\end{array}$ & $(126)$ & $\left(\begin{array}{lll}2 & 7 & 1\end{array}\right)$ & (227) & (19) & (274) \\
\hline
\end{tabular}

Total Prey Fish:

McNary Tailrace-

Restricted Zone (dam)

Prey/Predator

0.250

$-\quad-$

0

$\mathrm{mg} / \mathrm{g}$ Predator

2.81

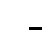

0

g/Predator

1.551

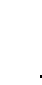

(Number of

(6)

(0)

(0)

John Day Poolexcluding McNary

Prey/Predator

0.126

0.383

0.761

0.136

0.920

Restricted Zone

$\mathrm{mg} / \mathrm{g}$ Predator

2.69

$8.00 \quad 19.70$

$11.45 \quad 31.18$

g/Predator

$0.807 \quad 2.716 \quad 4.581 \quad 2.012$

8.832

(Number of

$(126)(271)(227)(19) \quad(274)$ 
Appendix Table 11. Daily consumption estimates of juvenile salmonids and total preyfish by smallmouth bass $(n=1,246)$ in John Day Reservoir during 1984; stratified by month for McNary tailrace restricted zone versus the remainder of the reservoir.

\begin{tabular}{|c|c|c|c|c|c|c|}
\hline \multirow{2}{*}{$\begin{array}{l}\text { Species Group/ } \\
\text { Station } \\
\text { Juvenile Salmonids: }\end{array}$} & \multirow{2}{*}{$\begin{array}{c}\text { Daily } \\
\text { Consumption } \\
\text { Statistic }\end{array}$} & \multicolumn{4}{|c|}{ Consumption Estimate by } & \multirow{2}{*}{$\frac{\text { Month }}{\text { August }}$} \\
\hline & & $\overline{\text { April }}$ & May & June & July & \\
\hline \multirow{4}{*}{$\begin{array}{l}\text { McNary Tailrace- } \\
\text { Restricted Zone (dam) }\end{array}$} & Prey/Predator & & 0 & 0 & & 2.686 \\
\hline & $\mathrm{mg} / \mathrm{g}$ Predator & & 0 & 0 & & 1.98 \\
\hline & g/Predator & & 0 & 0 & & 0.706 \\
\hline & $\begin{array}{l}\text { (Number of } \\
\text { Predators) }\end{array}$ & (0) & (2) & (5) & $(0)$ & (3) \\
\hline \multirow{4}{*}{$\begin{array}{l}\text { John Day Pool- } \\
\text { excluding McNary } \\
\text { Restricted Zone }\end{array}$} & Prey/Predator & 0.011 & 0.007 & 0.009 & & 0.032 \\
\hline & $\mathrm{mg} / \mathrm{g}$ Predator & 0.01 & 0.03 & 0.124 & & 0.76 \\
\hline & g/Predator & 0.008 & 0.011 & 0.038 & & 0.172 \\
\hline & $\begin{array}{l}\text { (Number of } \\
\text { Predators) }\end{array}$ & (97) & (261) & $(543)$ & $(0)$ & (335) \\
\hline \multicolumn{7}{|l|}{ Total Prey Fish } \\
\hline \multirow{4}{*}{$\begin{array}{l}\text { McNary Tailrace- } \\
\text { Restricted Zone (dam) }\end{array}$} & Prey/Predator & & 0.370 & 0.199 & - & 5.372 \\
\hline & $\mathrm{mg} / \mathrm{g}$ Predator & & 7.71 & 1.11 & - & 3.45 \\
\hline & g/Predator & & 2.953 & 0.491 & - & 1.227 \\
\hline & $\begin{array}{l}\text { (Number of } \\
\text { Predators) }\end{array}$ & $(0)$ & (2) & (5) & (0) & (3) \\
\hline \multirow{3}{*}{$\begin{array}{l}\text { John Day Pool- } \\
\text { excluding McNary } \\
\text { Restricted Zone }\end{array}$} & Prey/Predator & 0.383 & 0.319 & 0.452 & - & 2.174 \\
\hline & mg/g Predator & 4. 77 & 4. 77 & 10.70 & - & 33.19 \\
\hline & $\begin{array}{l}\text { g/Predator } \\
\text { (Number of } \\
\text { Predators) } \\
\end{array}$ & $\begin{array}{l}3.811 \\
(97)\end{array}$ & $\begin{array}{l}1.765 \\
(261)\end{array}$ & $\begin{array}{r}3.27 \\
(543)\end{array}$ & $\frac{-}{(0)}$ & $\begin{array}{l}7.477 \\
(335)\end{array}$ \\
\hline
\end{tabular}


Appendix Table 12. Daily consumption estimates of juvenile salmonids and total preyfish by smallmouth bass $(\mathrm{n}=1,676)$ in John Day Reservoir during 1985; stratified by month for McNary tailrace restricted zone versus the remainder of the reservoir.

\begin{tabular}{|c|c|c|c|c|c|c|}
\hline \multirow[t]{2}{*}{$\begin{array}{l}\text { Species Group/ } \\
\text { Station }\end{array}$} & \multirow{2}{*}{$\begin{array}{c}\text { Daily } \\
\text { Consumption } \\
\text { Statistic }\end{array}$} & \multicolumn{4}{|c|}{ Consumption Estimate by } & \multirow{2}{*}{$\frac{\text { Month }}{\text { August }}$} \\
\hline & & $\overline{\text { April }}$ & May & June & July & \\
\hline \multirow{4}{*}{$\begin{array}{l}\text { McNary Tailrace- } \\
\text { Restricted Zone (dam) }\end{array}$} & Prey/Predator & 0 & 0 & 0 & - & - \\
\hline & $\mathrm{mg} / \mathrm{g}$ Predator & 0 & 0 & 0 & - & - \\
\hline & g/Predator & 0 & 0 & 0 & - & - \\
\hline & $\begin{array}{l}\text { (Number of } \\
\text { Predators) }\end{array}$ & (2) & (1) & (1) & (0) & $(0)$ \\
\hline \multirow{4}{*}{$\begin{array}{l}\text { John Day Pool- } \\
\text { excluding McNary } \\
\text { Restricted Zone }\end{array}$} & Prey/Predator & 0 & 0.009 & 0.043 & 0.056 & 0.077 \\
\hline & $\mathrm{mg} / \mathrm{g}$ Predator & 0 & 0.05 & 0.61 & 4.19 & 4.35 \\
\hline & g/Predator & 0 & 0.014 & 0.159 & 0.713 & 1.168 \\
\hline & $\begin{array}{l}\text { (Number of } \\
\text { Predators) }\end{array}$ & $(147)$ & $(522)$ & (511) & $(148)$ & $(344)$ \\
\hline \multicolumn{7}{|l|}{ Total Prey Fish: } \\
\hline \multirow{4}{*}{$\begin{array}{l}\text { McNary Tailrace- } \\
\text { Restricted Zone (dam) }\end{array}$} & Prey/Predator & 0.610 & 0 & 0 & - & - \\
\hline & mg/g Predator & 3.15 & 0 & 0 & - & - \\
\hline & g/Predator & 4.209 & 0 & 0 & - & - \\
\hline & $\begin{array}{l}\text { (Number of } \\
\text { Predators) }\end{array}$ & (2) & (1) & (1) & (0) & $(0)$ \\
\hline \multirow{4}{*}{$\begin{array}{l}\text { John Day Pool- } \\
\text { excluding McNary } \\
\text { Restricted Zone }\end{array}$} & Prey/Predator & 0.261 & 0.366 & 0.899 & 1.700 & 1.696 \\
\hline & $\mathrm{mg} / \mathrm{g}$ Predator & 6.12 & 10.99 & 28.59 & 76.74 & 43.86 \\
\hline & g/Predator & 3.066 & 3.254 & 7.424 & 13.046 & 11.778 \\
\hline & $\begin{array}{l}\text { (Number of } \\
\text { Predators) }\end{array}$ & (147) & $(522)$ & (511) & $(148)$ & (344) \\
\hline
\end{tabular}

